\title{
Spectral, thermal, molecular modeling and biological studies on mono- and binuclear complexes derived from oxalo bis(2,3-butanedionehydrazone)
}

\author{
Ahmed El-Asmy ${ }^{*}$, Bakir Jeragh and Mayada Ali
}

\begin{abstract}
Background: Hydrazones and their metal complexes were heavily studied due to their pharmacological applications such as antimicrobial, anticonvulsant analgesic, anti-inflammatory and anti-cancer agents. This work aims to synthesize and characterize novel complexes of $\mathrm{VO}^{2+}, \mathrm{Co}^{2+}, \mathrm{Ni}^{2+}, \mathrm{Cu}^{2+}, \mathrm{Zn}^{2+}, \mathrm{Zr}^{4+}$ and $\mathrm{Pd}^{2+}$ ions with oxalo bis(2,3-butanedione-hydrazone). Single crystals of the ligand have been grown and analyzed.

Results: Oxalo bis(2,3-butanedionehydrazone) $[\mathrm{OBH}]$ has a monoclinic crystal with $\mathrm{P} 121 / \mathrm{n} 1$ space group. The $\mathrm{VO}^{2+}, \mathrm{CO}^{2+}, \mathrm{Ni}^{2+}, \mathrm{Cu}^{2+}, \mathrm{Zn}^{2+}, \mathrm{Zr}^{4+}$ and $\mathrm{Pd}^{2+}$ complexes have the formulas: $\left[\mathrm{VO}(\mathrm{OBH}-\mathrm{H})_{2}\right] \cdot \mathrm{H}_{2} \mathrm{O},\left[\mathrm{CO}(\mathrm{OBH})_{2} \mathrm{Cl}\right] \mathrm{Cl} \cdot 1 / 2 \mathrm{EtOH}$, $\left[\mathrm{Ni}_{2}(\mathrm{OBH}) \mathrm{Cl}_{4}\right] \cdot \mathrm{H}_{2} \mathrm{O} \cdot \mathrm{EtOH},\left[\mathrm{Cu}(\mathrm{OBH})_{2} \mathrm{Cl}_{2}\right] \cdot 2 \mathrm{H}_{2} \mathrm{O},\left[\mathrm{Zn}(\mathrm{OBH}-\mathrm{H})_{2}\right],\left[\mathrm{Zr}(\mathrm{OBH}) \mathrm{Cl}_{4}\right] \cdot 2 \mathrm{H}_{2} \mathrm{O}$, and $\left[\mathrm{Pd}_{2}(\mathrm{OBH})\left(\mathrm{H}_{2} \mathrm{O}\right)_{2} \mathrm{Cl}_{4}\right] \cdot 2 \mathrm{H}_{2} \mathrm{O} \cdot \mathrm{All}$ complexes are nonelectrolytes except $\left[\mathrm{CO}(\mathrm{OBH})_{2} \mathrm{Cl}\right] \mathrm{Cl} \cdot 1 / 2 \mathrm{EtOH}$. OBH ligates as: neutral tetradentate (NNOO) in the $\mathrm{Ni}^{2+}$ and $\mathrm{Pd}^{2+}$ complexes; neutral bidentate $(\mathrm{OO})$ in $\left[\mathrm{Co}(\mathrm{OBH})_{2} \mathrm{Cl}\right] \mathrm{Cl} \cdot 1 / 2 \mathrm{EtOH}$, $\left[\mathrm{Zr}(\mathrm{OBH}) \mathrm{Cl}_{4}\right] \cdot 2 \mathrm{H}_{2} \mathrm{O}$ and $\left[\mathrm{Cu}(\mathrm{OBH})_{2} \mathrm{Cl}_{2}\right] \cdot 2 \mathrm{H}_{2} \mathrm{O}$ and monobasic bidentate $(\mathrm{OO})$ in the $\mathrm{Zn}^{2+}$ and $\mathrm{VO}^{2+}$ complexes. The NMR $\left({ }^{1} \mathrm{H}\right.$ and $\left.{ }^{13} \mathrm{C}\right)$ spectra support these data. The results proved a tetrahedral for the $\mathrm{Zn}^{2+}$ complex; square-planar for $\mathrm{Pd}^{2+}$; mixed stereochemistry for $\mathrm{Ni}^{2+}$; square-pyramid for $\mathrm{CO}^{2+}$ and $\mathrm{VO}^{2+}$ and octahedral for $\mathrm{Cu}^{2+}$ and $\mathrm{Zr}^{4+}$ complexes. The TGA revealed the outer and inner solvents as well as the residual part. The molecular modeling of $\left[\mathrm{Ni}_{2}(\mathrm{OBH}) \mathrm{Cl}_{4}\right] \cdot \mathrm{H}_{2} \mathrm{O} \cdot \mathrm{EtOH}$ and $\left[\mathrm{CO}(\mathrm{OBH})_{2} \mathrm{Cl}\right] \mathrm{Cl} \cdot 1 / 2 \mathrm{EtOH}$ are drawn and their molecular parameters proved that the presence of two metals stabilized the complex more than the mono metal. The complexes have variable activities against some bacteria and fungi. $\left[\mathrm{Zr}(\mathrm{OBH}) \mathrm{Cl}_{4}\right] \cdot 2 \mathrm{H}_{2} \mathrm{O}$ has the highest activity. $\left[\mathrm{CO}(\mathrm{OBH})_{2} \mathrm{Cl}\right] \mathrm{Cl} \cdot 1 / 2 \mathrm{EtOH}$ has more activity against Fusarium.
\end{abstract}

Conclusion: Oxalo bis(2,3-butanedionehydrazone) structure was proved by X-ray crystallography. It coordinates with some transition metal ions as neutral bidentate; mononegative bidentate and neutral tetradentate. The complexes have tetrahedral, square-planar and/or octahedral structures. The $\mathrm{VO}^{2+}$ and $\mathrm{Co}^{2+}$ complexes have square-pyramid structure. $\left[\mathrm{Cu}(\mathrm{OBH})_{2} \mathrm{Cl}_{2}\right] \cdot 2 \mathrm{H}_{2} \mathrm{O}$ and $\left[\mathrm{Ni}_{2}(\mathrm{OBH}) \mathrm{Cl}_{4}\right] \cdot \mathrm{H}_{2} \mathrm{O} \cdot \mathrm{EtOH}$ decomposed to their oxides while $\left[\mathrm{VO}(\mathrm{OBH}-\mathrm{H})_{2}\right] \cdot \mathrm{H}_{2} \mathrm{O}$ to vanadium. The energies obtained from molecular modeling calculation for $\left[\mathrm{Ni}_{2}(\mathrm{OBH}) \mathrm{Cl}_{4}\right] \cdot \mathrm{H}_{2} \mathrm{O} \cdot \mathrm{EtOH}$ are less than those for $\left[\mathrm{CO}(\mathrm{OBH})_{2} \mathrm{Cl}\right] \mathrm{Cl} \cdot 1 / 2 \mathrm{EtOH}$ indicating the two metals stabilized the complex more than mono metal. The Co(II) complex is polar molecule while the $\mathrm{Ni}(\mathrm{II})$ is non-polar.

\footnotetext{
*Correspondence: aelasmy@yahoo.com

Chemistry Department, Faculty of Science, Kuwait University, 5969

Kuwait city, Safat 1360, Kuwait
} provided you give appropriate credit to the original author(s) and the source, provide a link to the Creative Commons license, and indicate if changes were made. The Creative Commons Public Domain Dedication waiver (http://creativecommons.org/ publicdomain/zero/1.0/) applies to the data made available in this article, unless otherwise stated. 


\section{Graphical abstract:}

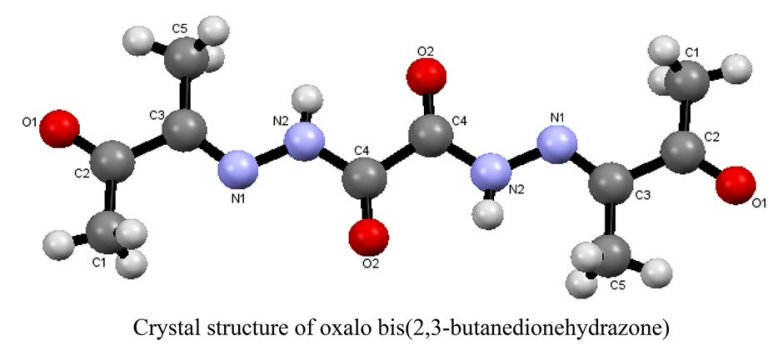

Keywords: Hydrazones, Spectra, TGA, Biological activity, X-ray crystallography

\section{Background}

Hydrazones and their metal complexes are heavily studied compounds which have many pharmacological applications such as antimicrobial, anticonvulsant analgesic, anti-inflammatory and anti-cancer agents. Acetylpyridine and benzoylpyridine hydrazones were used as reagents against brain tumor and are highly cytotoxic to glioma cells [1]. Interest has been focused on hydrazone complexes to study their anti-parasitic, fungicidal and bactericidal properties [2, 3]. 2,3-Butanedione monoxime possessed cardio protective properties related to the inhibition of cross-bridge force development [4]. Heterocyclic compounds containing nitrogen have much attention due to their activity as antitumor, anti-inflammation, anti-pyretic, antiviral, anti-microbial, insecticides and fungicides [5-7]. Isonicotinyl hydrazone complexes of 2-acetylpyridine, pyrrolyl-2-carboxaldehyde, 2,5-dihydroxy-acetophenone, $\mathrm{N}$-isonicotinamido-furfuraldimine, 2-thiophenecarbonyl and 3-(N-methyl)-isatin were reported [8-12]. The $\mathrm{Ni}(\mathrm{II})$ and $\mathrm{Cu}(\mathrm{II})$ complexes of 2,3-butanedione bis(N(3)substituted-thiosemicarbazones) were studied and some of these compounds were solved by $x$-ray crystallography [13]. The crystal structures of $[\mathrm{Cu}(\mathrm{HxPip}-2 \mathrm{H})]$ (HxPip = 3,4-hexanedione bis(3-piperidylthiosemicarbazone) and $[\mathrm{Cu}(\mathrm{HxHexim}-2 \mathrm{H})](\mathrm{HxHexim}=3$,4-hexanedione bis(3hexa-methyleneiminylthiosemicarbazone) were solved having a square-planar geometry [14]. Binuclear complexes of $\mathrm{VO}^{2+}, \mathrm{Co}^{2+}, \mathrm{Ni}^{2+}, \mathrm{Cu}^{2+}$ and $\mathrm{Zn}^{2+}$ with oxalyl bis(diacetylmonoximehydrazone) were characterized as 2:2 (M:L) and an octahedral geometry for $\mathrm{VO}^{2+}$, tetrahedral for $\mathrm{Zn}^{2+}$ and square-planar for the rest complexes were proposed [15]. On continuation to our work on bis(hydrazones) and their complexes [16, 17], this work aims to synthesize and characterize novel complexes of $\mathrm{VO}^{2+}, \mathrm{Co}^{2+}, \mathrm{Ni}^{2+}, \mathrm{Cu}^{2+}, \mathrm{Zn}^{2+}, \mathrm{Zr}^{4+}$ and $\mathrm{Pd}^{2+}$ ions with oxalo bis(2,3-butanedione-hydrazone). Single crystals for the ligand have been grown and analyzed. Trials to grow crystals for the complexes were failed, so molecular modeling for the $\mathrm{Co}(\mathrm{II})$ and $\mathrm{Ni}$ (II) complexes were done.

\section{Experimental}

$\mathrm{VOSO}_{4} \cdot 2 \mathrm{H}_{2} \mathrm{O}, \mathrm{CoCl}_{2} \cdot 6 \mathrm{H}_{2} \mathrm{O}, \mathrm{NiCl}_{2} \cdot 6 \mathrm{H}_{2} \mathrm{O}, \mathrm{CuCl}_{2} \cdot 2 \mathrm{H}_{2} \mathrm{O}$, $\mathrm{ZnCl}_{2} \cdot 2 \mathrm{H}_{2} \mathrm{O}, \mathrm{K}_{2} \mathrm{PdCl}_{4}$ and $\mathrm{ZrCl}_{4}$, diethyl oxalate, hydrazine hydrate, 2,3-butanedione, ethanol, diethyl ether, DMF and DMSO were obtained from the BDH chemicals.

\section{Synthesis of oxalo bis(2,3-butanedionehydrazone) [OBH]}

$\mathrm{OBH}$ was prepared by heating under reflux a suspension $(6 \mathrm{~g}, 0.05 \mathrm{~mol})$ of oxalic acid dihydrazide in $50 \mathrm{~mL}$ EtOH and $8.6 \mathrm{ml}(0.1 \mathrm{~mol})$ of 2,3-butanedione on a heating mantle for $10 \mathrm{~h}$. The precipitate thus formed was filtered off, recrystallized from ethanol and finally dried. It was characterized by elemental analysis and spectral studies. The ${ }^{1} \mathrm{H}$ NMR spectrum of the ligand showed signals at $\delta=11.924(\mathrm{~s}, 2 \mathrm{H})$ and $2.129(\mathrm{~s}, 6 \mathrm{H}) \mathrm{ppm}$ for the $\mathrm{NH}$ and $\mathrm{CH}_{3}$ protons. Its ${ }^{13} \mathrm{C} \mathrm{NMR}$ showed peaks at $196.65,167.58,148.81$ and $23.90 \mathrm{ppm}$ for $(\mathrm{C}=\mathrm{O})_{\text {ketonic }}$ $(\mathrm{C}=\mathrm{O})_{\text {amidic }}, \mathrm{C}=\mathrm{N}$ and $\mathrm{CH}_{3}$, respectively.

\section{Preparation of the metal complexes}

The metal complexes were prepared by reacting calculated amounts corresponding to $2: 1$ ratio [M:L] in $50 \mathrm{~mL}$ $\mathrm{EtOH}$ and the mixture was heated under reflux for 6-8 h. In the preparation of $\mathrm{VO}^{2+}$ complex, $0.1 \mathrm{~g}$ of sodium acetate was added to raise the $\mathrm{pH}(\sim 8)$ and precipitating the complex. The formed precipitates were filtered off, washed with hot water, hot ethanol and diethyl ether and finally dried in a vacuum desiccator over anhydrous silica gel. Attempts to grow single crystals for the complexes were done but unsuccessful.

\section{Analysis and equipment}

Carbon, hydrogen and nitrogen content of the compounds were determined at the Microanalytical Unit (Varian Micro V1.5.8, CHNS Mode, 15073036) of Kuwait University. The metal content was determined using ICP-OES GBC Quantium Sequential at Kuwait University. The mass spectra were recorded on a GCMS Thermo-DFS (BG_FAB) mass spectrometer. The 
melting points were measured on a Griffin melting point apparatus. The conductance for $10^{-3} \mathrm{~mol} \mathrm{~L}^{-1}$ DMSO solution of the compounds was measured on Orion 3 STAB Conductivity Bridge. The IR spectra were recorded as $\mathrm{KBr}$ discs on a FT/IR-6300 type A (400$4000 \mathrm{~cm}^{-1}$ ). The electronic spectra of the complexes were recorded on a Cary 5 UV-vis spectrophotometer, varian $(200-900 \mathrm{~nm})$. The ${ }^{1} \mathrm{H}$ NMR spectra of the ligand and the diamagnetic complexes were recorded in DMSO-d6, on a Bruker WP 200 SY Spectrometer $(400 \mathrm{MHz})$ at room temperature using tetramethylsilane (TMS) as an external standard. The magnetic measurements were carried out on a Johnson-Matthey magnetic balance, UK. The TGA thermograms were recorded $\left(25-800{ }^{\circ} \mathrm{C}\right)$ on a Shimadzu TGA-60; the nitrogen flow and heating rate were $50 \mathrm{ml} / \mathrm{min}$ and $10{ }^{\circ} \mathrm{C} \mathrm{min}{ }^{-1}$, respectively. The $\mathrm{X}$-ray single crystal diffraction data were collected on a Rigaku R-Axis Rapid diffractometer using filtered Mo-K $\alpha$-radiation. The structure was solved by the direct methods and expanded using Fourier techniques at Kuwait University. The ligand and its complexes were investigated for antimicrobial activity against Bacillus, Aspergillus, Escherichia coli, Pennicillium and Fusarium as reported earlier [15]. All molecular calculations were carried out by HyperChem 7.51 software package. The molecular geometry of the $\mathrm{Co}^{2+}$ and $\mathrm{Ni}^{2+}$ complexes are first optimized at molecular mechanics $(M M+)$ level. Semi empirical method PM3 is then used for optimizing the full geometry of the system using Polak-Ribiere (conjugate gradient) algorithm and Unrestricted Hartee-Fock (UHF) is employed keeping RMS gradient of $0.01 \mathrm{kcal} / \AA \mathrm{mol}$.

\section{Results and discussion}

\section{Crystal analysis of $\mathrm{OBH}$}

The crystal structure of OBH is shown in Structure 1. Its refinement data are summarized in Table 1 while the bond lengths and bond angles are presented in Table 2 . OBH was crystalized as monoclinic system and P 121/n1 space group with molecular weight of 254.25. The $\mathrm{N}_{1}-$ $\mathrm{C}_{3}, \mathrm{O}_{1}-\mathrm{C}_{2}$ and $\mathrm{O}_{2}-\mathrm{C}_{4}$ distances are 1.283(3), 1.210(3) and $1.206 \AA$, respectively, indicating true double bond; the amidic carbonyl has value slightly higher than the ketonic carbonyl. The $\mathrm{N}_{2}-\mathrm{C}_{4}$ and $\mathrm{N}_{1}-\mathrm{N}_{2}$ are 1.351(4) and $1.381 \AA$ indicating single bonds. All bond angles are between 115 and 127 and $109.5^{\circ}$ meaning the trigonal and tetrahedral geometries with $\mathrm{sp}^{2}$ and $\mathrm{sp}^{3}$ hybridization. The presence of lone pair of electrons on $\mathrm{N}_{1}$ in $\mathrm{C}_{3} \mathrm{~N}_{1} \mathrm{~N}_{2}$ reduces the angle from $120^{\circ}$ to $115.7^{\circ}$. The bond angle of $\mathrm{N}_{2}-\mathrm{C}_{4}-\mathrm{C}_{4}$ reduces to $110.6^{\circ}$, in consistent with some distortion, while that of $\mathrm{O}_{2}-\mathrm{C}_{4}-\mathrm{N}_{2}$ increases to $126.9^{\circ}$ due to the existence of two more electronegative atoms (O atoms).

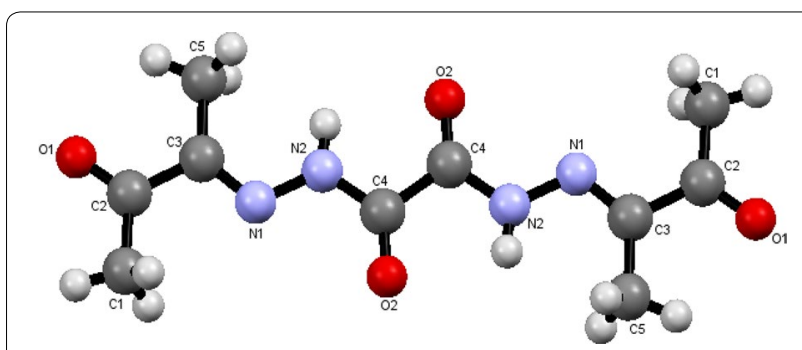

Structure 1 Crystal structure of oxalo bis(2,3-butanedionehydrazone)

Table 1 Crystallographic data for OBH crystal

\begin{tabular}{ll}
\hline Identification code & OBH \\
\hline Chemical formula & $\mathrm{C}_{10} \mathrm{H}_{14} \mathrm{~N}_{4} \mathrm{O}_{4}$ \\
Formula weight & 254.25 \\
Temperature & $296(2) \mathrm{K}$ \\
Wavelength & $1.54178 \AA$ \\
Crystal size & $0.020 \times 0.120 \times 0.230 \mathrm{~mm}$ \\
Crystal habit & Clear light colorless flakes \\
Crystal system & Monoclinic \\
Space group & $\mathrm{P} 121 / \mathrm{n} 1$ \\
Unit cell dimensions & $\mathrm{a}=6.3630(5) \AA, \mathrm{a}=90^{\circ}$ \\
& $\mathrm{b}=4.6609(4) \AA=91.37^{\circ}$ \\
Volume & $\mathrm{C}=20.7562(19) \AA, \gamma=90^{\circ}$ \\
Z & $615.40(9) \AA^{3}$ \\
Density (calculated) & 2 \\
Absorption coefficient & $1.372 \mathrm{~g} / \mathrm{cm}^{3}$ \\
F (000) & $0.915 \mathrm{~mm}^{-1}$ \\
\hline
\end{tabular}

\section{Analytical data}

The data of $\mathrm{CHN}$ and metal contents of the complexes are presented in Table 3. The values confirm mononuclear complexes: $\left[\mathrm{VO}(\mathrm{OBH}-\mathrm{H})_{2}\right] \cdot \mathrm{H}_{2} \mathrm{O},\left[\mathrm{Co}(\mathrm{OBH})_{2} \mathrm{Cl}\right]$ $\mathrm{Cl} \cdot \frac{1}{2} \mathrm{EtOH}, \quad\left[\mathrm{Cu}(\mathrm{OBH})_{2} \mathrm{Cl}_{2}\right] \cdot 2 \mathrm{H}_{2} \mathrm{O}, \quad\left[\mathrm{Zn}(\mathrm{OBH}-\mathrm{H})_{2}\right]$, $\left[\mathrm{Zr}(\mathrm{OBH}) \mathrm{Cl}_{4}\right] \cdot 2 \mathrm{H}_{2} \mathrm{O}$ and binuclear complexes: $\left[\mathrm{Ni}_{2}(\mathrm{OBH})\right.$ $\left.\mathrm{Cl}_{4}\right] \cdot \mathrm{H}_{2} \mathrm{O} \cdot \mathrm{EtOH}$ and $\left[\mathrm{Pd}_{2}(\mathrm{OBH})\left(\mathrm{H}_{2} \mathrm{O}\right)_{2} \mathrm{Cl}_{4}\right] \cdot 2 \mathrm{H}_{2} \mathrm{O}$. All complexes are colored, solid and stable towards air and moisture at room temperature. They have high melting points and are insoluble in most common organic solvents and completely soluble in DMSO. The molar conductance values (Table 3) of $10^{-3} \mathrm{~mol} \mathrm{~L}^{-1}$ DMSO solution proved the non-electrolytic nature. The measured value for the $\mathrm{Co}$ (II) complex supports the formation of $\left[\mathrm{Co}(\mathrm{OBH})_{2} \mathrm{Cl}\right]^{+} \mathrm{Cl}^{-} .1 / 2 \mathrm{EtOH}[18]$.

\section{IR and NMR ( $\left({ }^{1} \mathrm{H}\right.$ and $\left.{ }^{13} \mathrm{C}\right)$ spectra}

$\mathrm{OBH}$ showed the characteristic bands for $v(\mathrm{NH}), v(\mathrm{C}=\mathrm{O})$ [ketonic and amidic] and $v(\mathrm{C}=\mathrm{N})$ vibrations at 3325, 1701 and 1605, respectively in its IR spectrum (Fig. 1a). 
Table 2 Bond lengths and bond angles of $\mathrm{OBH}$

\begin{tabular}{|c|c|c|c|}
\hline Bond & Length & Bond & Length \\
\hline $\mathrm{O} 1-\mathrm{C} 2 \mathrm{I}$ & $1.210(3)$ & $\mathrm{O} 2-\mathrm{C} 4$ & $1.206(3)$ \\
\hline $\mathrm{N} 1-\mathrm{C} 3$ & $1.283(3)$ & $\mathrm{N} 1-\mathrm{N} 2$ & $1.381(3)$ \\
\hline $\mathrm{N} 2-\mathrm{C} 4$ & $1.351(4)$ & $\mathrm{N} 2-\mathrm{H} 7$ & 0.86 \\
\hline $\mathrm{C} 1-\mathrm{C} 2$ & $1.479(4)$ & $\mathrm{C} 1-\mathrm{H} 1$ & 0.96 \\
\hline $\mathrm{C} 1-\mathrm{H} 2$ & 0.96 & $\mathrm{C} 1-\mathrm{H} 3$ & 0.96 \\
\hline $\mathrm{C} 2-\mathrm{C} 3$ & $1.506(4)$ & $\mathrm{C} 3-\mathrm{C} 5$ & $1.486(4)$ \\
\hline C4-C4\#1 & $1.529(6)$ & $\mathrm{C} 5-\mathrm{H} 5$ & 0.96 \\
\hline $\mathrm{C} 5-\mathrm{H} 4$ & 0.96 & $\mathrm{C} 5-\mathrm{H} 6$ & 0.96 \\
\hline Bond & Angle $\left({ }^{\circ}\right)$ & Bond & Angle $\left({ }^{\circ}\right)$ \\
\hline $\mathrm{C} 3-\mathrm{N} 1-\mathrm{N} 2$ & $115.7(2)$ & $\mathrm{C} 4-\mathrm{N} 2-\mathrm{N} 1$ & $120.6(2)$ \\
\hline $\mathrm{C} 4-\mathrm{N} 2-\mathrm{H} 7$ & 119.7 & $\mathrm{~N} 1-\mathrm{N} 2-\mathrm{H} 7$ & 119.7 \\
\hline $\mathrm{C} 2-\mathrm{C} 1-\mathrm{H} 1$ & 109.5 & $\mathrm{C} 2-\mathrm{C} 1-\mathrm{H} 2$ & 109.5 \\
\hline $\mathrm{H} 1-\mathrm{C} 1-\mathrm{H} 2$ & 109.5 & $\mathrm{C} 2-\mathrm{C} 1-\mathrm{H} 3$ & 109.5 \\
\hline $\mathrm{H} 1-\mathrm{C} 1-\mathrm{H} 3$ & 109.5 & $\mathrm{H} 2-\mathrm{C} 1-\mathrm{H} 3$ & 109.5 \\
\hline $\mathrm{O} 1-\mathrm{C}_{2}-\mathrm{C} 1$ & $122.0(3)$ & $\mathrm{O} 1-\mathrm{C} 2-\mathrm{C} 3$ & $117.9(3)$ \\
\hline $\mathrm{C} 1-\mathrm{C} 2-\mathrm{C} 3$ & $120.1(3)$ & $\mathrm{N} 1-\mathrm{C} 3-\mathrm{C} 5$ & $126.6(3)$ \\
\hline $\mathrm{N} 1-\mathrm{C} 3-\mathrm{C} 2$ & $115.0(3)$ & C5-C3-C2 & $118.4(3)$ \\
\hline $\mathrm{O} 2-\mathrm{C} 4-\mathrm{N} 2$ & $126.9(3)$ & $\mathrm{O} 2-\mathrm{C} 4-\mathrm{C} 4 \# 1$ & $122.4(3)$ \\
\hline $\mathrm{N} 2-\mathrm{C} 4-\mathrm{C} 4 \# 1$ & $110.6(3)$ & $\mathrm{C} 3-\mathrm{C} 5-\mathrm{H} 5$ & 109.5 \\
\hline $\mathrm{C} 3-\mathrm{C} 5-\mathrm{H} 4$ & 109.5 & $\mathrm{H} 5-\mathrm{C} 5-\mathrm{H} 4$ & 109.5 \\
\hline $\mathrm{C} 3-\mathrm{C} 5-\mathrm{H} 6$ & 109.5 & $\mathrm{H} 5-\mathrm{C} 5-\mathrm{H} 6$ & 109.5 \\
\hline $\mathrm{H} 4-\mathrm{C} 5-\mathrm{H} 6$ & 109.5 & & \\
\hline
\end{tabular}

Inspections of the IR spectral data of the complexes, Table 4, three modes are suggested. The ${ }^{1} \mathrm{H}$ NMR spectrum showed the $\mathrm{NH}$ and $\mathrm{CH}_{3}$ protons at $11.924(\mathrm{~s}, 2 \mathrm{H})$ and $2.129(\mathrm{~s}, 6 \mathrm{H}) \mathrm{ppm}$, respectively. On the other hand, the ${ }^{13} \mathrm{C}$ NMR spectrum have multiple peaks corresponding to $(\mathrm{C}=\mathrm{O})_{\text {ketoni, }}(\mathrm{C}=\mathrm{O})_{\text {amidic }}, \mathrm{C}=\mathrm{N}$ and $\mathrm{CH} 3$ groups at $196.65,167.58,148.81$ and $23.90 \mathrm{ppm}$.
In the first mode, $\mathrm{OBH}$ acts as a neutral bidentate ligand in $\left[\mathrm{Co}(\mathrm{OBH})_{2} \mathrm{Cl}\right] \mathrm{Cl} \cdot 1 / 2 \mathrm{EtOH}$ (Structure 2), $\left[\mathrm{Cu}(\mathrm{OBH})_{2} \mathrm{Cl}_{2}\right] \cdot 2 \mathrm{H}_{2} \mathrm{O}$ and $\left[\mathrm{Zr}(\mathrm{OBH}) \mathrm{Cl}_{4}\right] \cdot 2 \mathrm{H}_{2} \mathrm{O}$ coordinating through the two amidic carbonyl groups based on the following observations: the $\mathrm{v}(\mathrm{C}=\mathrm{O})$ band observed at $1701 \mathrm{~cm}^{-1}$ in ligand spectrum was shifted to $1686-$ $1699 \mathrm{~cm}^{-1}$ in complexes having little intensity indicating that the two amidic carbonyl groups $\left(\mathrm{C}=\mathrm{O}_{\text {amidic }}\right)$ participated in bonding while the other two carbonyl $\left(\mathrm{C}=\mathrm{O}_{\text {ketonic }}\right)$ still at the same position. The new band at $464-495 \mathrm{~cm}^{-1}$ is due to $\mathrm{v}(\mathrm{M}-\mathrm{O})$ vibration [19]. The $\mathrm{v}(\mathrm{C}=\mathrm{N})$ at $1605 \mathrm{~cm}^{-1}$ appeared very weak, less intensity with little shift to higher wavenumber in the $\mathrm{Co}(\mathrm{II})$ and $\mathrm{Cu}$ (II) complexes and to lower wavenumber in the $\mathrm{Zr}(\mathrm{IV})$ complex $\left(1585 \mathrm{~cm}^{-1}\right)$.

In the second mode, $\mathrm{OBH}$ acts as a mononegative bidentate in $\mathrm{Zn}^{2+}$ and $\mathrm{VO}^{2+}$ complexes coordinating through the two amidic carbonyl (enolic form), from each ligand molecule. The shift of $\mathrm{v}(\mathrm{C}=\mathrm{O})$ to lower or higher wavenumbers with appearance of $\mathrm{v}(\mathrm{C}=\mathrm{N})^{*}, \mathrm{v}(\mathrm{C}-\mathrm{O})$ (due to enolization of one amidic group) [20] and $v(\mathrm{M}-\mathrm{O})$ at 1550, 1140 and $463 \mathrm{~cm}^{-1}$ indicates the participation of carbonyl group in bonding. In the $\mathrm{VO}^{2+}$ complex, the band observed at $3412 \mathrm{~cm}^{-1}$ is attributed to hydrated water [21] and absence of sulfate bands indicates enol type of complexes. The ${ }^{1} \mathrm{H}$ NMR spectrum of $[\mathrm{Zn}(\mathrm{OBH}-$ $\mathrm{H})_{2}$ ] showed splitting of $\mathrm{NH}$ signal as a result of conversion of one of $\mathrm{NHC}=\mathrm{O}$ to $\mathrm{N}=\mathrm{C}-\mathrm{OH}$ and the existence of the others without participation (Structure 3). The signals of $\mathrm{CH}_{3}$ protons appeared at the same position as in ligand spectrum. In its ${ }^{13} \mathrm{C}$ NMR, peaks of both ketonic and amidic groups still at the same position with appearance of a new one at $166.21 \mathrm{ppm}$ although one of the $\mathrm{C}=\mathrm{O}_{\text {amidic }}$ changed to enol form. Also, the appearance of $\mathrm{C}=\mathrm{N}$ as doublet peak in 149.44-148.44 ppm range confirming enolization. In the ${ }^{13} \mathrm{C}$ NMR spectrum

Table 3 Elemental analysis and some physical properties of $\mathrm{OBH}$ and its complexes

\begin{tabular}{|c|c|c|c|c|c|c|c|c|}
\hline Compound, empirical formula & $\begin{array}{l}\text { M.W. (Found, } \\
\text { m/e) }\end{array}$ & Color & M.P. $\left({ }^{\circ} \mathrm{C}\right)$ & $\begin{array}{l}\Lambda\left(\mathrm{Ohm}^{-1} \mathrm{~cm}^{2}\right. \\
\left.\mathrm{mol}^{-1}\right)^{\mathrm{a}}\end{array}$ & $\begin{array}{l}\text { C \% Calcd. } \\
\text { (Found) }\end{array}$ & $\begin{array}{l}\mathrm{H} \% \text { Calcd. } \\
\text { (Found) }\end{array}$ & $\begin{array}{l}\text { N \% Calcd. } \\
\text { (Found) }\end{array}$ & $\begin{array}{l}\text { M \% Calcd. } \\
\text { (Found) }\end{array}$ \\
\hline $\mathrm{OBHC}{ }_{10} \mathrm{H}_{14} \mathrm{~N}_{4} \mathrm{O}_{4}$ & $254.25(255.30)$ & White & $247-249$ & 1.76 & $46.66(47.04)$ & $5.75(5.55)$ & $22.70(22.34)$ & - \\
\hline $\begin{array}{l}{\left[\mathrm{Co}(\mathrm{OBH})_{2} \mathrm{Cl}\right] \mathrm{Cl} .1 / 2 \mathrm{EtOH}} \\
\mathrm{C}_{21} \mathrm{H}_{31} \mathrm{~N}_{8} \mathrm{O}_{8.5} \mathrm{Cl}_{2} \mathrm{Co}\end{array}$ & 661.395 & Pale brown & $>325$ & 48.0 & $38.13(38.13)$ & $4.72(4.94)$ & $16.94(16.68)$ & $8.91(8.63)$ \\
\hline$\left[\mathrm{Zr}(\mathrm{OBH}) \mathrm{Cl}_{4}\right] \cdot 2 \mathrm{H}_{2} \mathrm{O} \mathrm{C} \mathrm{C}_{10} \mathrm{H}_{18} \mathrm{~N}_{4} \mathrm{O}_{6} \mathrm{Cl}_{4} \mathrm{Zr}$ & $523.33(523.4)$ & Pale orange & $>325$ & 20.10 & $22.95(22.63)$ & $3.47(3.87)$ & $10.70(10.79)$ & $17.70(17.20)$ \\
\hline$\left[\mathrm{Zn}(\mathrm{OBH}-\mathrm{H})_{2}\right] \mathrm{C}_{20} \mathrm{H}_{26} \mathrm{~N}_{8} \mathrm{O}_{8} \mathrm{Zn}$ & 571.84 & Yellowish white & $>325$ & 2.62 & $42.09(42.49)$ & $4.58(5.08)$ & $19.59(19.39)$ & \\
\hline$\left[\mathrm{VO}(\mathrm{OBH}-\mathrm{H})_{2}\right] \cdot \mathrm{H}_{2} \mathrm{O} \mathrm{C}_{20} \mathrm{H}_{26} \mathrm{~N}_{8} \mathrm{O}_{10} \mathrm{~V}$ & 591.86 & Brown & 293 & 9.74 & $40.58(39.99)$ & $4.77(4.98)$ & $18.93(18.28)$ & $8.45(7.93)$ \\
\hline$\left[\mathrm{Cu}(\mathrm{OBH})_{2} \mathrm{Cl}_{2}\right] \cdot 2 \mathrm{H}_{2} \mathrm{O} \mathrm{C}_{20} \mathrm{H}_{32} \mathrm{~N}_{8} \mathrm{O}_{10} \mathrm{Cl}_{2} \mathrm{Cu}$ & 678.99 & Yellowish green & $>325$ & 22.50 & $35.37(35.35)$ & $4.45(4.58)$ & $16.50(16.07)$ & $9.34(9.08)$ \\
\hline $\begin{array}{l}{\left[\mathrm{Ni}_{2}(\mathrm{OBH}) \mathrm{Cl}_{4}\right] \cdot \mathrm{H}_{2} \mathrm{O} \cdot \mathrm{EtOHC} \mathrm{C}_{20} \mathrm{H}_{22} \mathrm{~N}_{4} \mathrm{O}-} \\
{ }_{6} \mathrm{Cl}_{4} \mathrm{Ni}_{2}\end{array}$ & $577.62(371.7)^{b}$ & Reddish brown & $>325$ & 37.30 & $24.95(24.53)$ & $3.84(4.11)$ & 9.70 (9.39) & $20.34(20.54)$ \\
\hline $\begin{array}{l}{\left[\mathrm{Pd}_{2}(\mathrm{OBH})\left(\mathrm{H}_{2} \mathrm{O}\right)_{2} \mathrm{Cl}_{4}\right] \cdot 2 \mathrm{H}_{2} \mathrm{O} \mathrm{C}{ }_{10} \mathrm{H}_{22} \mathrm{~N}_{4} \mathrm{O}-} \\
{ }_{4} \mathrm{Cl}_{4} \mathrm{Pd}_{2}\end{array}$ & $618.18(620.30)$ & Brown & $>325$ & 24.48 & $20.63(20.96)$ & $3.81(4.20)$ & $9.62(9.39)$ & \\
\hline
\end{tabular}

a Molar conductance values for $0.001 \mathrm{~mol} \mathrm{~L}^{-1}$ DMSO solution

b The value represents $\mathrm{Ni}(\mathrm{OBH}) \mathrm{Cl} \cdot 1 / 2 \mathrm{EtOH}$ 

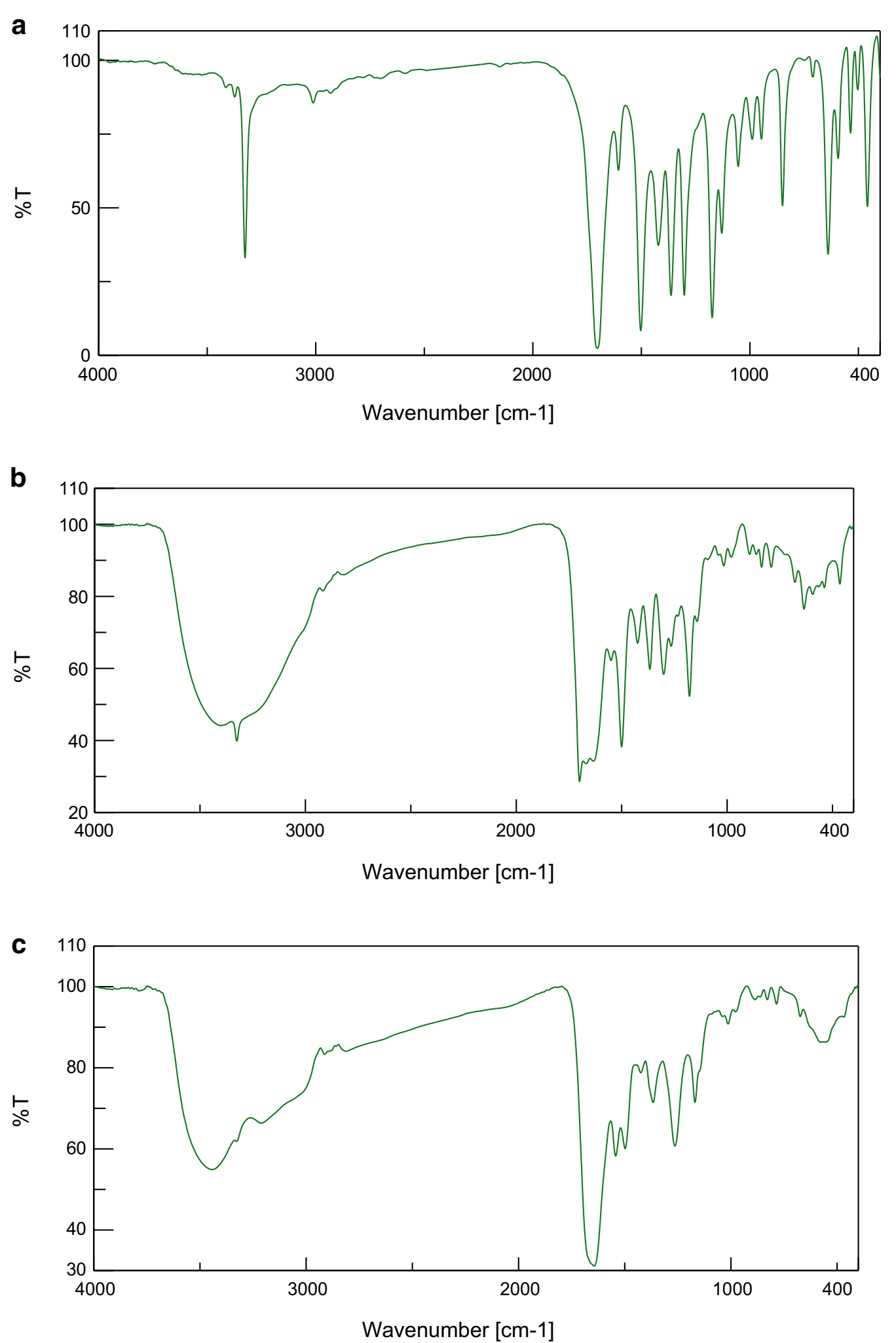

Fig. 1 IR spectra of $\mathrm{OBH}(\mathbf{a}) ;\left[\mathrm{Ni}_{2}(\mathrm{OBH}) \mathrm{Cl}_{4}\right] \cdot \mathrm{H}_{2} \mathrm{O} \cdot \mathrm{EtOH}(\mathbf{b})$ and $\left[\mathrm{Pd}_{2}(\mathrm{OBH}) \mathrm{Cl}_{4}\right] \cdot 6 \mathrm{H}_{2} \mathrm{O}(\mathbf{c})$ 
Table 4 IR band assignments of $\mathrm{OBH}$ and its complexes

\begin{tabular}{lllllllll}
\hline Compound & $\mathbf{v}(\mathbf{N H})$ & $\mathbf{v}(\mathbf{C}=\mathbf{O})$ & $\mathbf{v}(\mathbf{C}=\mathbf{N})$ & $\mathbf{v}(\mathbf{C}=\mathbf{N})^{\mathbf{a}}$ & $\mathbf{v}(\mathbf{C}-\mathbf{O})$ & $\mathbf{v}(\mathbf{M}-\mathbf{O})$ & $\mathbf{v}(\mathbf{M}-\mathbf{N})$ & Observations \\
\hline $\mathrm{OBH}$ & $3325(\mathrm{~s})$ & $1701(\mathrm{~s})$ & $1605(\mathrm{~m})$ & - & - & - & - & \\
{$\left[\mathrm{Co}(\mathrm{OBH})_{2} \mathrm{Cl}\right] \mathrm{Cl} \cdot 1 / 2 \mathrm{EtOH}$} & $3325(\mathrm{~m})$ & $1699(\mathrm{~s})$ & $1612(\mathrm{w})$ & - & - & $464(\mathrm{~m})$ & - & $3415(\mathrm{br}) \mathrm{for} \mathrm{EtOH}$ \\
{$\left[\mathrm{Zr}(\mathrm{OBH}) \mathrm{Cl}_{4}\right] \cdot 2 \mathrm{H}_{2} \mathrm{O}$} & $3326(\mathrm{vbr})^{\mathrm{a}}$ & $1686(\mathrm{~m})$ & $1585(\mathrm{~m})$ & - & - & $495(\mathrm{br})$ & - & \\
{$\left[\mathrm{Zn}(\mathrm{OBH}-\mathrm{H})_{2}\right]$} & - & $1699(\mathrm{~s})$ & $1605(\mathrm{w})$ & $1550(\mathrm{w})$ & $1140(\mathrm{w})$ & $463(\mathrm{~s})$ & - & \\
{$\left[\mathrm{VO}(\mathrm{OBH}-\mathrm{H})_{2}\right] \cdot \mathrm{H}_{2} \mathrm{O}$} & - & $1696(\mathrm{~s})$ & $1608(\mathrm{w})$ & $1552(\mathrm{w})$ & $1142(\mathrm{w})$ & $463(\mathrm{~m})$ & - & $3412(\mathrm{br})$ for $\mathrm{H}_{2} \mathrm{O} ; \mathrm{v}(\mathrm{V}=\mathrm{O})$ at 961 \\
$\left.\left[\mathrm{Cu}(\mathrm{OBH})_{2} \mathrm{Cl}\right)_{2}\right] \cdot 2 \mathrm{H}_{2} \mathrm{O}$ & $3325(\mathrm{~m})$ & $1701(\mathrm{~s})$ & $1610(\mathrm{br})$ & - & - & $464(\mathrm{~m})$ & - & $3415(\mathrm{br})$ for $\mathrm{H}_{2} \mathrm{O}$ \\
{$\left[\mathrm{Ni}{ }_{2}(\mathrm{OBH}) \mathrm{Cl}_{4}\right] \cdot \mathrm{H}_{2} \mathrm{O} \cdot \mathrm{EtOH}$} & 3324 & $1676(\mathrm{br})$ & $1552(\mathrm{sh})$ & - & - & $464(\mathrm{~m})$ & 539 & $3389(\mathrm{br})$ for $\mathrm{H}_{2} \mathrm{O}$ \\
{$\left[\mathrm{Pd}_{2}(\mathrm{OBH})\left(\mathrm{H}_{2} \mathrm{O}\right)_{2} \mathrm{Cl}\right] \cdot 2 \mathrm{H}_{2} \mathrm{O}$} & $3327(\mathrm{w})$ & 1644 & 1542 & - & - & 467 & 542 & $3441(\mathrm{br})$ for $\mathrm{H}_{2} \mathrm{O}$ \\
\hline
\end{tabular}

a The value for $\mathrm{NH}$ and $\mathrm{H}_{2} \mathrm{O}$

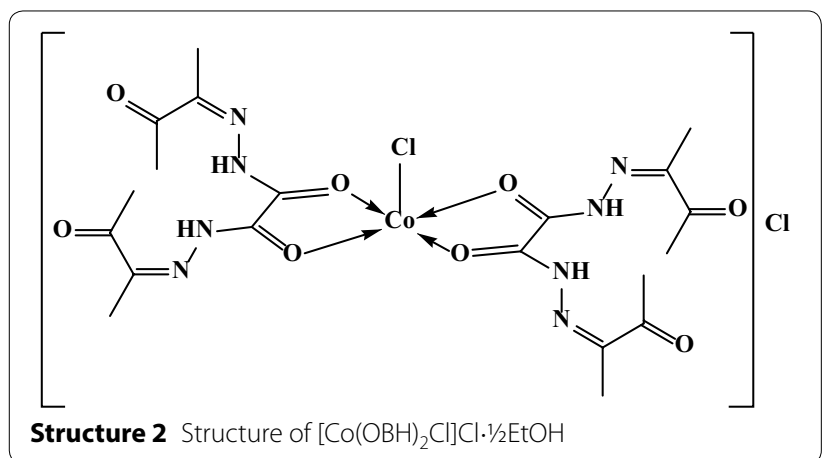

Structure 3 Structures of $\mathrm{VO}^{2+}$ and $\mathrm{Zn}^{2+}$ complexes

of $\mathrm{VO}^{2+}$ complex, the peaks at $172.50,168.44-167.47$, $149.60-148.86,124.68$ and $24.98-24.30 \mathrm{ppm}$ are due to $(\mathrm{C}=\mathrm{O})_{\text {ketonic }},(\mathrm{C}=\mathrm{O})_{\text {amidic }}$ free, $(\mathrm{C}=\mathrm{O})_{\text {amidic }}$ bonded,
$(\mathrm{C}=\mathrm{N}),(\mathrm{C}=\mathrm{N})^{*},(\mathrm{C}-\mathrm{O})$ and $\mathrm{CH}_{3}$, respectively. The appearance of $(\mathrm{C}=\mathrm{N}) *$ (due to conversion of $\mathrm{NHC}=\mathrm{O}$ to $\left.\mathrm{N}^{*}=\mathrm{C}-\mathrm{O}\right)$ and $(\mathrm{C}-\mathrm{O})$ peaks confirm enolization process (Table 5).

The third mode confirmed neutral tetradentate but with two metal ions in $\left[\mathrm{Ni}_{2}(\mathrm{OBH}) \mathrm{Cl}_{4}\right] \cdot \mathrm{H}_{2} \mathrm{O} \cdot \mathrm{EtOH}$ (Structure 4) and $\left[\mathrm{Pd}_{2}(\mathrm{OBH})\left(\mathrm{H}_{2} \mathrm{O}\right)_{2} \mathrm{Cl}_{4}\right] \cdot 2 \mathrm{H}_{2} \mathrm{O}$ (Fig. 1b, c). The coordination sites are two azomethine nitrogens of the hydrazone moiety and two carbonyl groups of amidic moiety; each two donors chelated one metal ion. The shift of $\mathrm{v}(\mathrm{C}=\mathrm{N})$ to $1542 \mathrm{~cm}^{-1}$ and $\mathrm{v}(\mathrm{C}=\mathrm{O})_{\text {amidic }}$ to 1644 in the Pd(II) complex and to 1552 and 1676 in the Ni(II) complex together with appearance of $\mathrm{v}(\mathrm{M}-\mathrm{N})[22]$ and $\mathrm{v}(\mathrm{M}-\mathrm{O})$ bands at $\sim 465$ and $\sim 540 \mathrm{~cm}^{-1}$, respectively. In the $\mathrm{Ni}(\mathrm{II})$ complex, the band of carbonyl groups splitted to two at 1697 and $1676 \mathrm{~cm}^{-1}$; the first is due to ketonic group which is not participated in bonding. The NH band appeared very weak in $\mathrm{Ni}(\mathrm{II})$ complex and very broad in Pd(II) complex. Finally, the band at 3389 or $3441 \mathrm{~cm}^{-1}$ in $\mathrm{Ni}(\mathrm{II})$ or $\mathrm{Pd}(\mathrm{II})$ complex is due to hydrated water or ethanol.

\section{Mass spectra}

The data of FAB-mass spectra of $\mathrm{OBH}$ and some of its complexes are shown in Table 3. The mass spectrum of $\mathrm{OBH}$ showed the molecular ion peak (base peak) at $\mathrm{m} / \mathrm{z}=255.30$ (Calcd. 254.25) corresponding to $\mathrm{C}_{10} \mathrm{H}_{14} \mathrm{~N}_{4} \mathrm{O}_{4}$. The peaks shown at 212.2, 190.2, 130.2 and 73.1 are due to $\mathrm{C}_{8} \mathrm{H}_{11} \mathrm{~N}_{4} \mathrm{O}_{3}, \mathrm{C}_{7} \mathrm{H}_{11} \mathrm{~N}_{3} \mathrm{O}_{3}, \mathrm{C}_{4} \mathrm{H}_{5} \mathrm{~N}_{3} \mathrm{O}_{2}$ and $\mathrm{C}_{2} \mathrm{NO}_{2}$.

The mass spectrum of $\left[\mathrm{Zr}(\mathrm{OBH}) \mathrm{Cl}_{4}\right] \cdot 2 \mathrm{H}_{2} \mathrm{O}$ exhibits $\mathrm{m} / \mathrm{z}$ value of 523.5 (Calcd. 523.33) with $12 \%$ intensity. The value corresponds to $\mathrm{C}_{10} \mathrm{H}_{18} \mathrm{~N}_{4} \mathrm{O}_{6} \mathrm{Cl}_{4} \mathrm{Zr}$. Multi-peaks were observed ending with a peak at 69.0 (78 \% intensity) may corresponding to $6 \mathrm{C}$.

Moreover, the mass spectrum of $\left[\mathrm{Ni}_{2}(\mathrm{OBH})\right.$ $\left.\mathrm{Cl}_{4}\right] \cdot \mathrm{H}_{2} \mathrm{O} \cdot \mathrm{EtOH}$ has a value of 371.7 (the base peak) corresponding to $\mathrm{Ni}(\mathrm{OBH}) \mathrm{Cl} \cdot 1 \frac{1}{2} \mathrm{EtOH}$ meaning that this species is highly stable. Multi peaks were observed ending with one at 128.9 (intensity $65 \%$ ) due to $\mathrm{ZrO}_{2}$. 
Table $5{ }^{1} \mathrm{H}$ and ${ }^{13} \mathrm{C}$ NMR signals of $\mathrm{OBH}$ and its diamagnetic complexes

\begin{tabular}{|c|c|c|c|}
\hline Compound & $\mathrm{NH}$ & $\mathrm{CH}_{3}$ & ${ }^{13} \mathrm{C}$ signals \\
\hline $\mathrm{OBH}$ & $11.924(\mathrm{~s}, 2 \mathrm{H})$ & $2.129(\mathrm{~s}, 6 \mathrm{H})$ & $\begin{array}{l}196.65(\mathrm{C}=\mathrm{O})_{\text {ketonic }} \\
167.58 ;(\mathrm{C}=\mathrm{O})_{\text {amidic }} \\
148.81(\mathrm{C}=\mathrm{N}) \\
23.90\left(\mathrm{CH}_{3}\right)\end{array}$ \\
\hline$\left[\mathrm{Zn}(\mathrm{OBH}-\mathrm{H})_{2}\right]$ & $\begin{array}{l}11.781(\mathrm{~s}, 1 \mathrm{H}) \\
11.565(\mathrm{~s}, 1 \mathrm{H})\end{array}$ & $\begin{array}{l}2.371(\mathrm{~s}, 3 \mathrm{H}) \\
2.118(\mathrm{~s}, 3 \mathrm{H})\end{array}$ & $\begin{array}{l}196.68(\mathrm{C}=\mathrm{O})_{\text {ketonic }} \\
168.02(\mathrm{C}=\mathrm{O})_{\text {amidic }} \text { free } \\
166.21(\mathrm{C}=\mathrm{O})_{\text {amidic }} \text { bonded } \\
149.44(\mathrm{C}=\mathrm{N}),(\mathrm{C}=\mathrm{N})^{*} \\
23.94\left(\mathrm{CH}_{3}\right)\end{array}$ \\
\hline$\left[\mathrm{VO}(\mathrm{OBH}-\mathrm{H})_{2}\right] \cdot \mathrm{H}_{2} \mathrm{O}$ & $11.769(\mathrm{~s}, 1 \mathrm{H})$ & $\begin{array}{l}2.087(\mathrm{~s}, 3 \mathrm{H}) \\
2.053(\mathrm{~s}, 3 \mathrm{H})\end{array}$ & $\begin{array}{l}197.12(\mathrm{C}=\mathrm{O})_{\text {ketonic }} \\
172.50(\mathrm{C}=\mathrm{O})_{\text {amidic }}(\text { free }) \\
168.44-167.47(\mathrm{C}=\mathrm{O})_{\text {amidic }} \text { (bonded) } \\
149.60-148.86(\mathrm{C}=\mathrm{N}),(\mathrm{C}=\mathrm{N})^{*} \\
124.68(\mathrm{C}-\mathrm{O}) \\
24.68 ; 24.98\left(\mathrm{CH}_{3}\right)\end{array}$ \\
\hline$\left[\mathrm{Pd}_{2}(\mathrm{OBH})\left(\mathrm{H}_{2} \mathrm{O}\right)_{2} \mathrm{Cl}_{4}\right] \cdot 2 \mathrm{H}_{2} \mathrm{O}$ & $\begin{array}{l}11.766(\mathrm{~s}, 1 \mathrm{H}) \\
11.566(\mathrm{~s}, 1 \mathrm{H})\end{array}$ & $2.290(s, 6 H)$ & $\begin{array}{l}196.75(\mathrm{C}=\mathrm{O})_{\text {ketonic }} \\
167.98 ;(\mathrm{C}=\mathrm{O})_{\text {amidic }} \\
148.88(\mathrm{C}=\mathrm{N}) \\
22.90\left(\mathrm{CH}_{3}\right)\end{array}$ \\
\hline
\end{tabular}

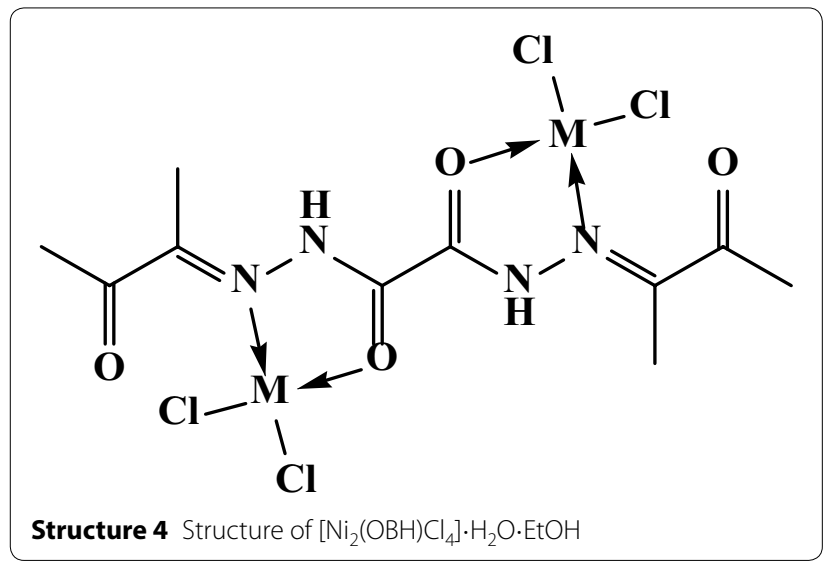

Magnetic moments and electronic spectra

The electronic spectral bands of the complexes as well as the magnetic moment values are presented in Table 6 . The DMSO solutions of complexes have the same color as in the solid complexes. OBH exhibits one absorption band at $38,460 \mathrm{~cm}^{-1}$ collectively due to $\pi \rightarrow \pi^{*}$ transitions of $\mathrm{C}=\mathrm{N}, \mathrm{C}=\mathrm{O}_{\text {ketonic }}$ and $\mathrm{C}=\mathrm{O}_{\text {amidic }}$ groups [23]. The broadness of the band may be due to existence of these groups in opposite sides. The two bands at 25,510 and $23,810 \mathrm{~cm}^{-1}$ in $\mathrm{Cu}$ (II) complex may be due to $\mathrm{N} \rightarrow$ MCT and $\mathrm{O} \rightarrow$ MCT [24]. The Ni(II) complex has only one band at $28,330 \mathrm{~cm}^{-1}$ due to $\mathrm{N} \rightarrow$ MCT while $\mathrm{Co}(\mathrm{II})$ and $\mathrm{Zr}(\mathrm{IV})$ have also one band but at 23,320 and $22,830 \mathrm{~cm}^{-1}$, respectively, due to $\mathrm{O} \rightarrow$ MCT.

Table 6 Magnetic moments, electronic spectra and molar extension coefficient of OBH and its complexes

\begin{tabular}{|c|c|c|c|c|}
\hline Compound & $\mu_{\text {eff }}(B M)$ & $\begin{array}{l}\text { Intraligand and charge transfer transition, } \mathrm{cm}^{-1} \\
\left({ }^{*} \varepsilon\right)\end{array}$ & $\mathrm{d}-\mathrm{d}$ transition $\mathrm{cm}^{-1}\left({ }^{*} \varepsilon\right)$ & Proposed structure \\
\hline $\mathrm{OBH}$ & - & $38,460(790)$ & - & \\
\hline$\left[\mathrm{Co}(\mathrm{OBH})_{2} \mathrm{Cl}\right] \mathrm{Cl} \cdot 1 / 2 \mathrm{EtOH}$ & 2.51 & 37,450 (195.8); 23,320 (115.8) & $15,250(94)$ & Square-pyramid \\
\hline$\left[\mathrm{Zr}(\mathrm{OBH}) \mathrm{Cl}_{4}\right] \cdot 2 \mathrm{H}_{2} \mathrm{O}$ & - & 36,495 (399); 22,830 (117.6) & - & Octahedral \\
\hline$\left[\mathrm{Zn}(\mathrm{OBH}-\mathrm{H})_{2}\right]$ & - & $37,450(530) ; 35,335(885)$ & - & Tetrahedral \\
\hline$\left[\mathrm{VO}(\mathrm{OBH}-\mathrm{H})_{2}\right] \cdot \mathrm{H}_{2} \mathrm{O}$ & 0.00 & 38,$060 ; 35,040 ; 29.210$ & & Square-pyramid \\
\hline$\left[\mathrm{Cu}(\mathrm{OBH})_{2} \mathrm{Cl}_{2}\right] \cdot 2 \mathrm{H}_{2} \mathrm{O}$ & 1.45 & 39,$840 ; 37,590 ; 25,510 ; 23,810(350)$ & 20,080 & Octahedral \\
\hline$\left[\mathrm{Ni}_{2}(\mathrm{OBH}) \mathrm{Cl}_{4}\right] \cdot \mathrm{H}_{2} \mathrm{O} \cdot \mathrm{EtOH}$ & $1.36^{\mathrm{a}}$ & 39,$840 ; 37,590 ; 28,330$ & 19,050 & Square-planar + tetrahedral \\
\hline$\left[\mathrm{Pd}_{2}(\mathrm{OBH})\left(\mathrm{H}_{2} \mathrm{O}\right)_{2} \mathrm{Cl}_{4}\right] \cdot 2 \mathrm{H}_{2} \mathrm{O}$ & 0.00 & 37,$540 ; 28,470$ & $21,500(310)$ & Square-pyramid \\
\hline
\end{tabular}

${ }^{*} \varepsilon$ is the molar extension coefficient $\left(\mathrm{mol}^{-1} \mathrm{~L}\right)$

a The value per one nickel atom 
$\left[\mathrm{Co}(\mathrm{OBH})_{2} \mathrm{Cl}\right] \mathrm{Cl} \cdot \frac{1}{2} / 2 \mathrm{EtOH}$ (pale brown) has $2.51 \mathrm{BM}$ magnetic moment which lies within the values reported for one unpaired electron of square-planar or squarepyramid $\mathrm{Co}(\mathrm{II})$ complexes [25] having $\mathrm{dsp}^{2}$ or $\mathrm{dsp}^{3}$ hybridization. Evidence is electronic spectrum which showed one band at $15,250 \mathrm{~cm}^{-1}$ with molar extension coefficient of $94 \mathrm{~mol}^{-1} \mathrm{~L}$. The spectrum resembled the spectra of the five-coordinate Co(II) complexes [26] and the square-pyramid is the suggested geometry.

The magnetic moment value, for each atom, in $\left[\mathrm{Ni}_{2}(\mathrm{OBH}-2 \mathrm{H}) \mathrm{Cl}_{4}\right] \cdot \mathrm{H}_{2} \mathrm{O} \cdot \mathrm{EtOH}$ is $1.36 \mathrm{BM}$ which is less than the normal values reported for tetrahedral or octahedral coordination containing two unpaired electrons. Its electronic spectrum showed a broad band at $19,050 \mathrm{~cm}^{-1}\left(\varepsilon=180 \mathrm{~mol}^{-1} \mathrm{~L}\right)$ typical of a square-planar structure with some distortion [26] may be of tetrahedral; the anomalous magnetic value is consistent with mixed stereochemistry (square-planar + tetrahedral) around the two nickel ions [27]. On the other hand, the diamagnetic nature of $\left[\mathrm{Pd}_{2}(\mathrm{OBH})\left(\mathrm{H}_{2} \mathrm{O}\right)_{2} \mathrm{Cl}_{4}\right] \cdot 2 \mathrm{H}_{2} \mathrm{O}$ proved the square-pyramid structure in which the metal is surrounded by NO donors, two chloro and one coordinated

Table 7 Decomposition steps of the complexes based on the thermogravimetric data

\begin{tabular}{|c|c|c|c|}
\hline Complex & $\begin{array}{l}\text { DTG } \\
\text { maximum } \\
\text { temp. }\left({ }^{\circ} \mathrm{C}\right)\end{array}$ & $\begin{array}{l}\text { Removing } \\
\text { species }\end{array}$ & $\begin{array}{l}\text { Weight loss } \\
\text { \% Found } \\
\text { (Calcd) }\end{array}$ \\
\hline \multirow{4}{*}{$\begin{array}{c}{\left[\mathrm{Co}(\mathrm{OBH})_{2} \mathrm{Cl}\right]} \\
\mathrm{Cl} \cdot 1 / 2 \mathrm{EtOH}\end{array}$} & 60 & $-1 / 2 \mathrm{Cl}_{2}+1 / 2 \mathrm{EtOH}$ & $6.36(8.84)$ \\
\hline & 319 & $-\mathrm{C}_{16} \mathrm{H}_{24} \mathrm{~N}_{4} \mathrm{O}_{6} \mathrm{Cl}$ & $60.45(61.05)$ \\
\hline & 500 & $-\mathrm{C}_{4} \mathrm{H}_{4} \mathrm{~N}_{2}$ & $11.77(12.11)$ \\
\hline & $>500$ & {$\left[\mathrm{CoO}_{4} \mathrm{~N}_{2}\right]$ (residue) } & $21.58(22.82)$ \\
\hline \multirow[t]{4}{*}[\mathrm{Zr}(\mathrm{OBH})\mathrm{Cl}_{4}]{$\cdot 2 \mathrm{H}_{2} \mathrm{O}$} & 76 & $-\left(\mathrm{Cl}_{2}+\mathrm{H}_{2} \mathrm{O}\right)$ & $16.12(16.99)$ \\
\hline & 313 & $-\left(\mathrm{H}_{2} \mathrm{O}+\mathrm{C}_{8} \mathrm{H}_{12} \mathrm{~N}_{2} \mathrm{O}_{2}\right)$ & $37.67(35.58)$ \\
\hline & 449 & $-\mathrm{Cl}_{2}$ & $12.44(13.55)$ \\
\hline & $>500$ & $\mathrm{C}_{2} \mathrm{~N}_{2} \mathrm{O}_{2} \mathrm{Zr}$ (residue) & $30.15(33.67)$ \\
\hline \multirow[t]{4}{*}[\mathrm{VO}(\mathrm{OBH}-\mathrm{H})_{2}]{$\cdot \mathrm{H}_{2} \mathrm{O}$} & 59 & $-\mathrm{H}_{2} \mathrm{O}$ & $3.65(3.04)$ \\
\hline & 289 & $-\mathrm{C}_{16} \mathrm{H}_{24} \mathrm{~N}_{4} \mathrm{O}_{6}$ & $61.57(62.24)$ \\
\hline & $405-590$ & $-\mathrm{C}_{4} \mathrm{H}_{4} \mathrm{~N}_{4} \mathrm{O}_{2}$ & $25.56(23.67)$ \\
\hline & $>600$ & V (residue) & 7.45 (8.53) \\
\hline \multirow[t]{4}{*}[\mathrm{Cu}(\mathrm{OBH})_{2}\mathrm{Cl}_{2}]{$\cdot 2 \mathrm{H}_{2} \mathrm{O}$} & 59 & $-2 \mathrm{H}_{2} \mathrm{O}$ & $4.29(5.31)$ \\
\hline & 291 & $-\mathrm{C}_{16} \mathrm{H}_{24} \mathrm{~N}_{4} \mathrm{O}_{6}$ & $54.90(54.26)$ \\
\hline & 374 & $-\mathrm{C}_{4} \mathrm{H}_{4} \mathrm{~N}_{4} \mathrm{O}_{3}$ & $25.56(26.37)$ \\
\hline & $>400$ & CuO (residue) & $12.30(11.71)$ \\
\hline \multirow{5}{*}{$\begin{array}{l}{\left[\mathrm{Ni}_{2}(\mathrm{OBH})\right.} \\
\left.\mathrm{Cl}_{4}\right] \cdot \mathrm{H}_{2} \mathrm{O} \cdot \mathrm{EtOH}\end{array}$} & 72 & $-\left(\mathrm{EtOH}+\mathrm{H}_{2} \mathrm{O}\right)$ & $13.51(11.08)$ \\
\hline & 368 & $-\left(\mathrm{Cl}_{2}+\mathrm{C}_{8} \mathrm{H}_{12} \mathrm{~N}_{2} \mathrm{O}_{2}\right)$ & $40.20(41.40)$ \\
\hline & 470 & $-\mathrm{Cl}_{2}$ & $11.20(12.27)$ \\
\hline & 550 & $-\mathrm{C}_{2} \mathrm{H}_{2} \mathrm{~N}_{2}$ & $8.00(9.35)$ \\
\hline & $>600$ & $2 \mathrm{NiO}$ (residue) & $27.09(25.87)$ \\
\hline \multirow{2}{*}{$\begin{array}{l}{\left[\mathrm{Pd}_{2}(\mathrm{OBH})\right.} \\
\left.\quad\left(\mathrm{H}_{2} \mathrm{O}\right)_{2} \mathrm{Cl}_{4}\right] \cdot 2 \mathrm{H}_{2} \mathrm{O}\end{array}$} & 75 & $-2 \mathrm{H}_{2} \mathrm{O}$ & $6.47(5.83)$ \\
\hline & 322 & $\begin{array}{l}-2 \mathrm{H}_{2} \mathrm{O}+2 \mathrm{Cl}_{2}+ \\
\mathrm{C}_{4} \mathrm{H}_{12}\end{array}$ & 38.49 (38.48) \\
\hline
\end{tabular}

water. The bands at 37,540 and $28,470 \mathrm{~cm}^{-1}$ are attributed to charge transfer transitions, probably $\mathrm{O} \rightarrow \mathrm{Pd}$ transition [28].

The electronic spectrum of $\left[\mathrm{Cu}(\mathrm{OBH})_{2} \mathrm{Cl}_{2}\right] \cdot \mathrm{H}_{2} \mathrm{O}$ exhibits one band with maximum at $20080 \mathrm{~cm}^{-1}$ assigned to the ${ }^{2} \mathrm{E}_{2 \mathrm{~g}} \rightarrow{ }^{2} \mathrm{~T}_{2 \mathrm{~g}}$ transition in an octahedral geometry [29]. The band is broad due to the Jhan-Teller effect which enhances the distortion of the octahedral geometry generally important for odd number occupancy of the $\mathrm{e}_{\mathrm{g}}$ level. The magnetic moment value (1.45 $\mathrm{BM})$ was found lower than the values reported for the $\mathrm{d}^{9}$-system containing one unpaired electron (1.73$2.25 \mathrm{BM}$ ) suggesting interactions between the copper centers.

\section{Thermal analysis}

The decomposition steps, the DTG maximum temperature and the removing species are shown in Table 7. The thermogram of $\left[\mathrm{Co}(\mathrm{OBH})_{2} \mathrm{Cl}\right] \mathrm{Cl} \cdot 1 \frac{1}{2} \mathrm{EtOH}$ showed three decomposition steps at mid- points of 60,319 and $500{ }^{\circ} \mathrm{C}$ corresponding to the removal of $1 / 2 \mathrm{Cl}_{2}+1 / 2 \mathrm{EtOH}$ (Found 6.36 \%; Calcd. $8.84 \%$ ); $\mathrm{C}_{16} \mathrm{H}_{24} \mathrm{~N}_{4} \mathrm{O}_{6} \mathrm{Cl}$ (Found $60.45 \%$; Calcd. $61.05 \%$ ) and $\mathrm{C}_{4} \mathrm{H}_{4} \mathrm{~N}_{2}$ (Found $11.77 \%$; Calcd $12.11 \%$ ) leaving $\left[\mathrm{CoO}_{4} \mathrm{~N}_{2}\right]$ moiety (Found $21.58 \%$; Calcd. $22.82 \%)$.

The TG curve of $\left[\mathrm{VO}(\mathrm{OBH}-\mathrm{H})_{2}\right] \cdot \mathrm{H}_{2} \mathrm{O}$ showed also three steps; the first (mid. point $56{ }^{\circ} \mathrm{C}$ ) represents the removal of the outside water molecule (Found $3.65 \%$; Calcd 3.04\%); the second (mid. point $289^{\circ} \mathrm{C}$ ) represents the loss of $\mathrm{C}_{16} \mathrm{H}_{24} \mathrm{~N}_{4} \mathrm{O}_{6}$ (Found $61.57 \%$; Calcd 62.24 \%) and the third for the repulsion of $\mathrm{C}_{4} \mathrm{H}_{4} \mathrm{~N}_{4} \mathrm{O}_{2}$ (Found 25.56 (Calcd. $23.67 \%$ ). The residue is vanadium metal (Found 7.45; Calcd $8.53 \%$ ).

$\left[\mathrm{Cu}(\mathrm{OBH})_{2} \mathrm{Cl}_{2}\right] \cdot 2 \mathrm{H}_{2} \mathrm{O}$ thermogram showed decomposition steps ending with copper oxide at Temp. $>400{ }^{\circ} \mathrm{C}$. The decomposition showed the removal of the two hydrated water in the first step at mid. point of $59^{\circ} \mathrm{C}$. The other two steps were observed at 291 and $374{ }^{\circ} \mathrm{C}$ corresponding to the removal of $\mathrm{C}_{16} \mathrm{H}_{24} \mathrm{~N}_{4} \mathrm{O}_{6}$ and $\mathrm{C}_{4} \mathrm{H}_{4} \mathrm{~N}_{4} \mathrm{O}_{3}$, respectively, leaving $\mathrm{CuO}$ as a residue.

The TG curve of $\left[\mathrm{Ni}_{2}(\mathrm{OBH}) \mathrm{Cl}_{4}\right] \cdot \mathrm{H}_{2} \mathrm{O} \cdot \mathrm{EtOH}$ showed four steps. The first at $72{ }^{\circ} \mathrm{C}$ is due to the removal of the outside water and $\mathrm{EtOH}$ (Found $13.51 \%$; Calcd. $11.08 \%)$. The second step $\left(368^{\circ} \mathrm{C}\right)$ represents the loss of $\mathrm{Cl}_{2}+\mathrm{C}_{8} \mathrm{H}_{12} \mathrm{~N}_{2} \mathrm{O}_{2}$ (Found $40.20 \%$; Calcd $41.40 \%$ ). The third step represents the repulsion of $\mathrm{Cl}_{2}$ (Found $11.20 \%$; Calcd. 12.27 \%). The fourth step (Found $8.00 \%$; Calcd. $9.35 \%)$ corresponding to the removal of $\mathrm{C}_{2} \mathrm{H}_{2} \mathrm{~N}_{2}$. The residue is $2 \mathrm{NiO}$ (Found 27.09 \%; Calcd. $25.87 \%$ ) (Fig. 2).

The thermogram of $\left[\mathrm{Zr}(\mathrm{OBH}) \mathrm{Cl}_{4}\right] \cdot 2 \mathrm{H}_{2} \mathrm{O}$ has $\mathrm{C}_{2} \mathrm{~N}_{2} \mathrm{O}_{2} \mathrm{Zr}$ as remaining residue above $500{ }^{\circ} \mathrm{C}$ with $30.15 \%$ (Calcd. $33.67 \%$ ). The first three steps observed at mid. points of 76,313 and $449{ }^{\circ} \mathrm{C}$ are corresponding to the removal of 


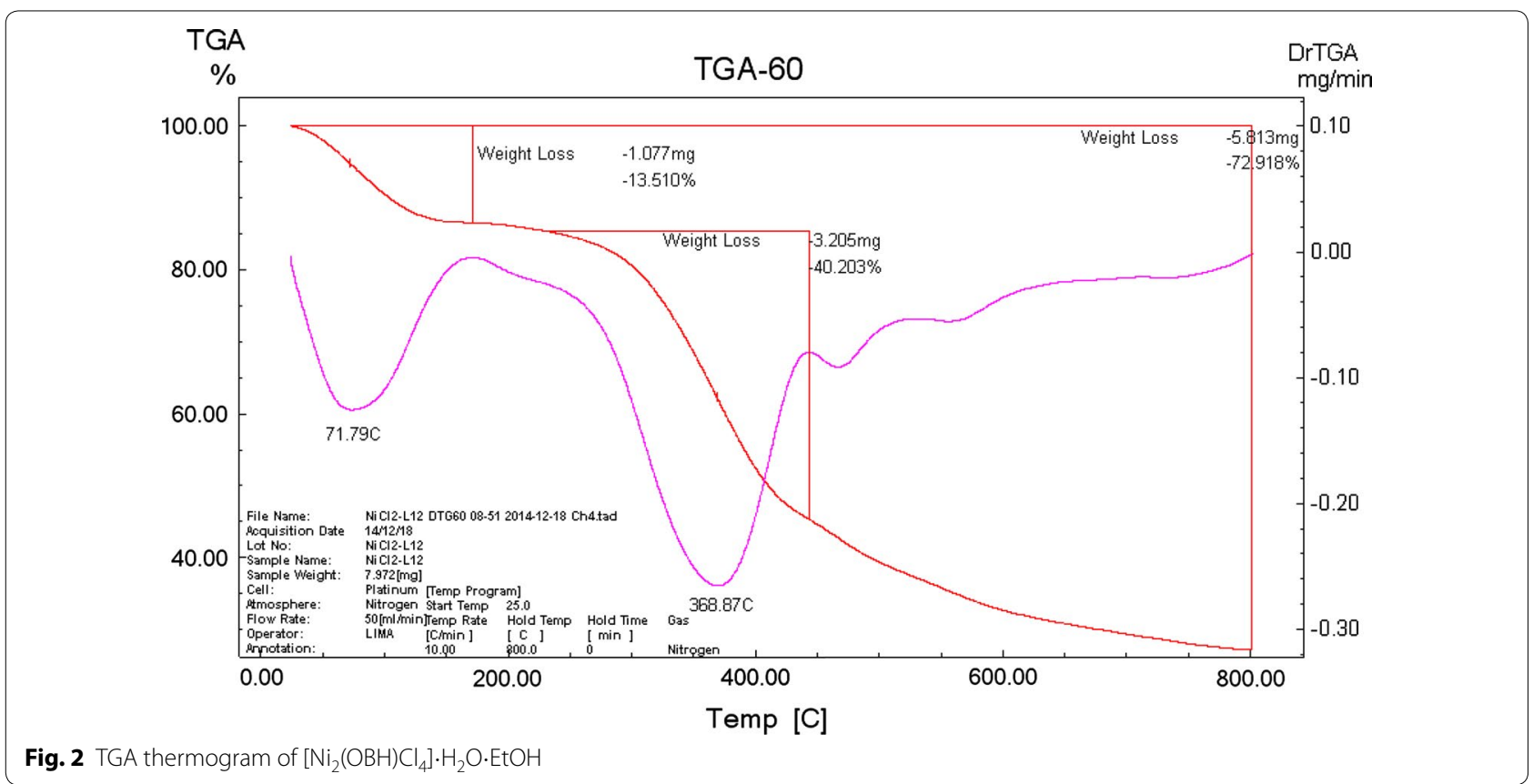

Fig. $2 \mathrm{TGA}$ thermogram of $\left[\mathrm{Ni}_{2}(\mathrm{OBH}) \mathrm{Cl}_{4}\right] \cdot \mathrm{H}_{2} \mathrm{O} \cdot \mathrm{EtOH}$

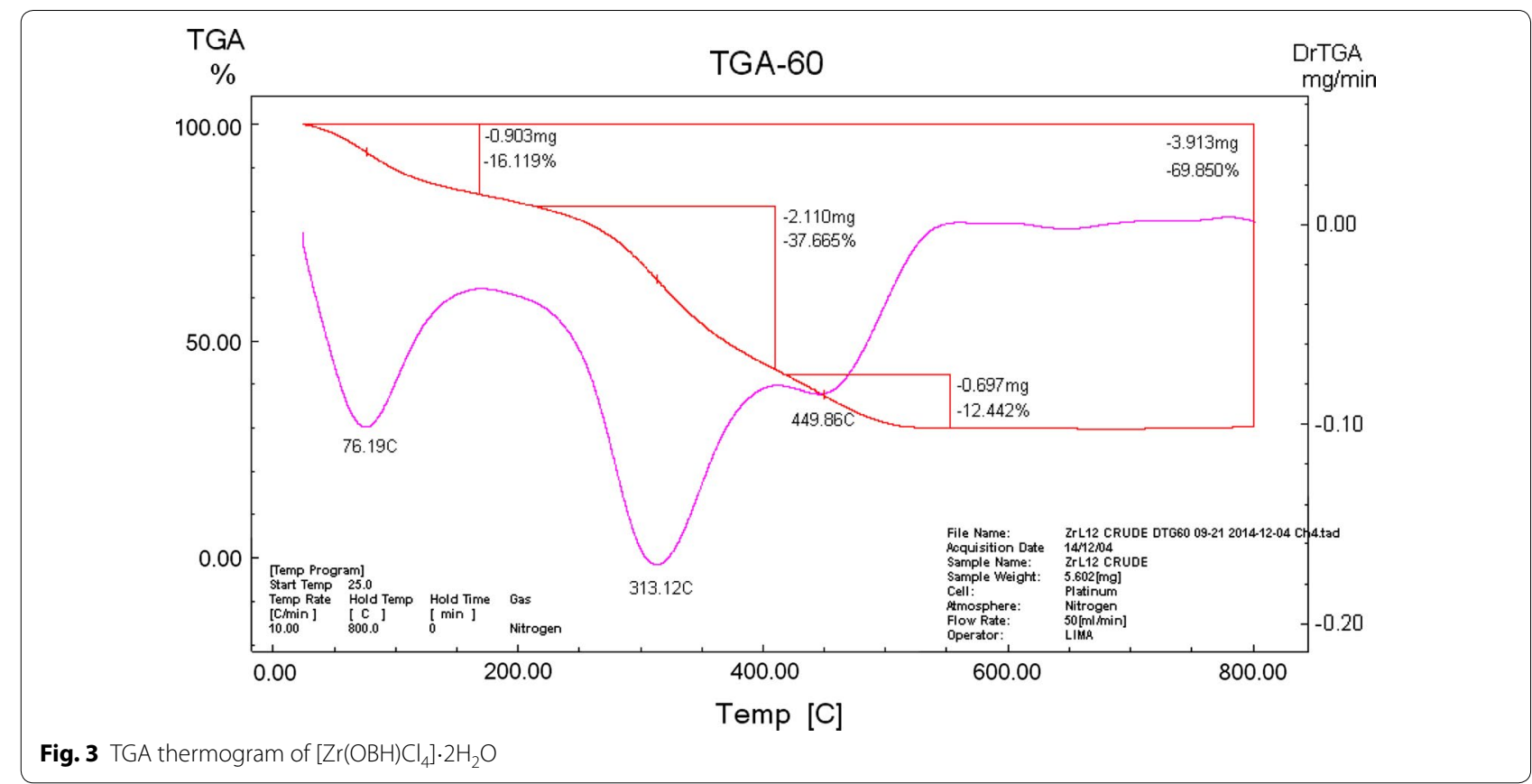

$\left(\mathrm{Cl}_{2}+\mathrm{H}_{2} \mathrm{O}\right) ;\left(\mathrm{H}_{2} \mathrm{O}+\mathrm{C}_{8} \mathrm{H}_{12} \mathrm{~N}_{2} \mathrm{O}_{2}\right)$ and $\mathrm{Cl}_{2}$, respectively (Fig. 3).

The thermogram of $\left[\mathrm{Pd}_{2}(\mathrm{OBH})\left(\mathrm{H}_{2} \mathrm{O}\right)_{2} \mathrm{Cl}_{4}\right] \cdot 2 \mathrm{H}_{2} \mathrm{O}$ showed two main steps at 75 and $322{ }^{\circ} \mathrm{C}$ due to the liberation of the outside water and $2 \mathrm{H}_{2} \mathrm{O}+2 \mathrm{Cl}_{2}+\mathrm{C}_{4} \mathrm{H}_{12}$, respectively. High residue $\%$ was found over $500{ }^{\circ} \mathrm{C}$.

\section{Molecular modeling}

Trials to grow single crystals for the investigated complexes were failed. In order to calculate the molecular parameters, $\quad\left[\mathrm{Co}(\mathrm{OBH})_{2} \mathrm{Cl}\right] \mathrm{Cl} \cdot \frac{1}{2} \mathrm{EtOH}$ and $\left[\mathrm{Ni}_{2}(\mathrm{OBH})\right.$ $\left.\mathrm{Cl}_{4}\right] \cdot \mathrm{H}_{2} \mathrm{O} \cdot \mathrm{EtOH}$ (Structure 5) are chosen and their data are presented in Table 8 . The bond lengths and the bond 


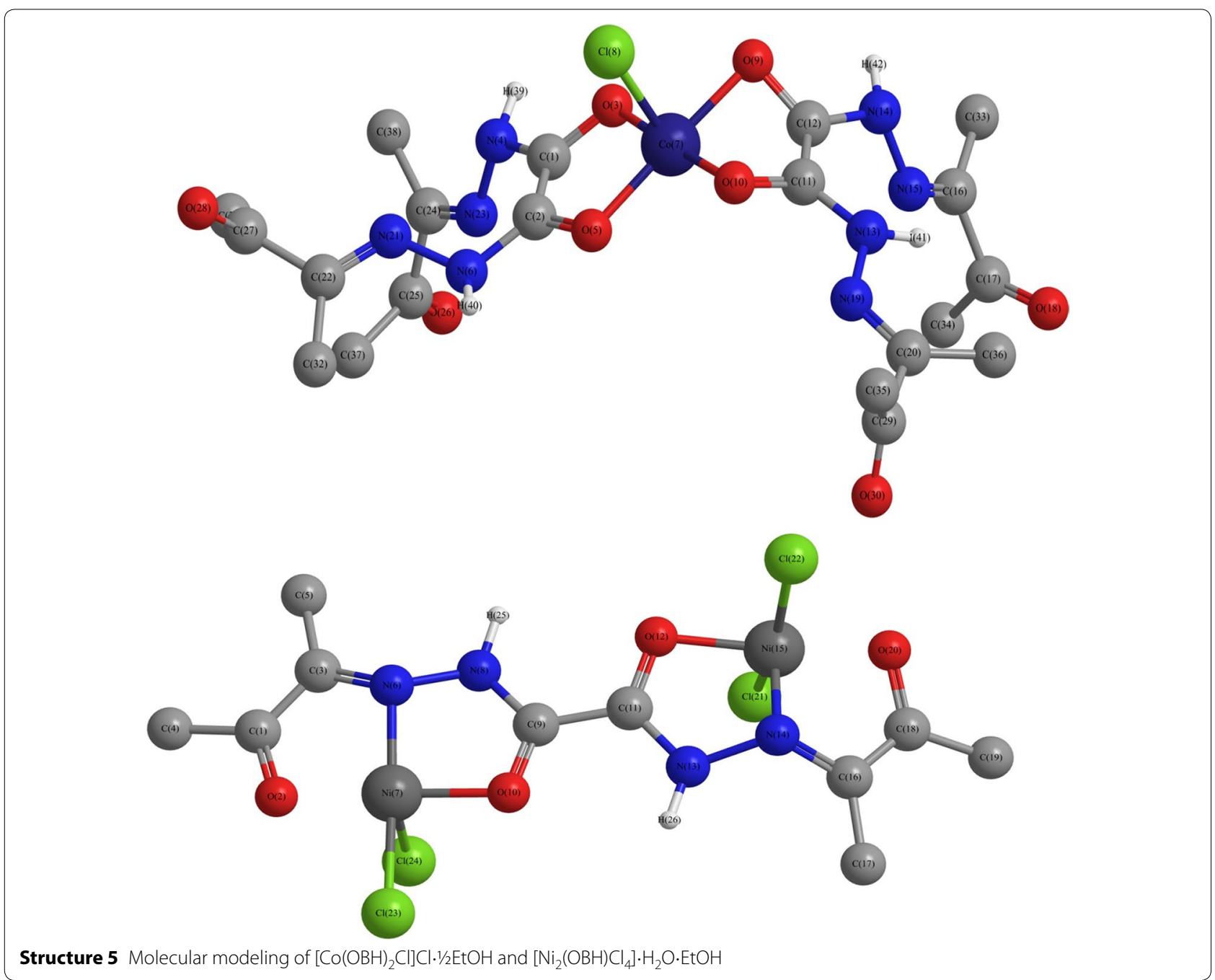

Table 8 Molecular parameters of the $\mathrm{Co}$ (II) and $\mathrm{Ni}$ (II) complexes

\begin{tabular}{|c|c|c|}
\hline Parameter & $\begin{array}{l}{\left[\mathrm{Co}(\mathrm{OBH})_{2} \mathrm{Cl}\right]} \\
\mathrm{Cl} \cdot 1 / 2 \mathrm{EtOH}\end{array}$ & $\begin{array}{l}{\left[\mathrm{Ni}_{2}(\mathrm{OBH})\right.} \\
\left.\mathrm{Cl}_{4}\right] \cdot \mathrm{H}_{2} \mathrm{O} \cdot \mathrm{EtOH}\end{array}$ \\
\hline Total energy $(\mathrm{kcal} / \mathrm{mol})$ & -174051.6072885 & -151380.5229794 \\
\hline Total energy (a.u.) & -277.368857336 & -241.240189251 \\
\hline Binding energy (kcal/mol) & -6649.8942255 & -3610.0626914 \\
\hline Isolated atomic energy ( $\mathrm{kcal} / \mathrm{mol})$ & |) -167401.7130630 & -147770.4602880 \\
\hline Electronic energy (kcal/mol) & -1559859.4974432 & -935598.9682580 \\
\hline Core-core interaction (kcal/mol) & 1385807.8901548 & 784218.4452785 \\
\hline Heat of formation (kcal/mol) & -261.3762255 & -159.9386914 \\
\hline Gradient (kcal/mol/Å) & 53.4569309 & 42.0607388 \\
\hline Dipole (Debyes) & 4.949 & 0.413 \\
\hline
\end{tabular}

angles are shown in Additional file 1: Tables S1 and S2. It is obvious that the energy values obtained for $\left[\mathrm{Ni}_{2}(\mathrm{OBH})\right.$ $\left.\mathrm{Cl}_{4}\right] \cdot \mathrm{H}_{2} \mathrm{O} \cdot \mathrm{EtOH}$ are less than those of $\left[\mathrm{Co}(\mathrm{OBH})_{2} \mathrm{Cl}\right]$
$\mathrm{Cl} \cdot 1 \frac{1}{2} \mathrm{EtOH}$ indicating that the presence of two metals stabilized the complex more than the mono metal lowering the energy. The dipole moment calculated for the Co(II) complex is $4.949 \mathrm{D}$ proving the polar nature of the complex. The value of $\mathrm{Ni}(\mathrm{II})$ complex is $0.413 \mathrm{D}$ indicating its non-polarity.

\section{Biological activity}

The antimicrobial activity of the metal complexes depends on the following factors: the chelate effect, i.e., bidentate ligands show higher antimicrobial activity than monodentate; the nature of the ligands; the total charge of the complex: cationic > neutral > anionic; the nature of the counter ion and the nuclearity of the metal center: binuclear are more active than mononuclear ones. It depends more on the metal center itself than on the geometry around the metal ion.

The antimicrobial activities of $\mathrm{OBH}$ and its complexes are examined against Bacillus, E. coli, Aspergillus, 
Table 9 Effect of ligand and its complexes on some microorganisms

\begin{tabular}{|c|c|c|c|c|c|}
\hline Compound & Bacillus & E. coli & $\begin{array}{l}\text { Asper- } \\
\text { gillus }\end{array}$ & Penicillium & Fusarium \\
\hline $\mathrm{OBH}$ & $\mathrm{Nil}$ & 2.0 & Nil & $\mathrm{Nil}$ & Nil \\
\hline $\begin{array}{c}{\left[\mathrm{Co}(\mathrm{OBH})_{2} \mathrm{Cl}\right]} \\
\mathrm{Cl} \cdot 1 / 2 \mathrm{EtOH}\end{array}$ & $\mathrm{Nil}$ & 1.0 & Nil & $\mathrm{Nil}$ & 15 \\
\hline$\left[\mathrm{Zr}(\mathrm{OBH}) \mathrm{Cl}_{4}\right] \cdot 2 \mathrm{H}_{2} \mathrm{O}$ & 10 & $\mathrm{Nil}$ & 4.0 & 9.0 & 8.0 \\
\hline$\left[\mathrm{Zn}(\mathrm{OBH}-\mathrm{H})_{2}\right]$ & $\mathrm{Nil}$ & 1.0 & Nil & Nil & 5.0 \\
\hline$\left[\mathrm{Cu}(\mathrm{OBH})_{2} \mathrm{Cl}_{2}\right] \cdot 2 \mathrm{H}_{2} \mathrm{O}$ & $\mathrm{Nil}$ & 2.0 & Nil & 5.0 & Nil \\
\hline $\begin{array}{l}{\left[\mathrm{Ni}_{2}(\mathrm{OBH})\right.} \\
\left.\mathrm{Cl}_{4}\right] \cdot \mathrm{H}_{2} \mathrm{O} \cdot \mathrm{EtOH}\end{array}$ & $\mathrm{Nil}$ & 2.0 & Nil & Nil & Nil \\
\hline $\begin{array}{l}{\left[\mathrm{Pd}_{2}(\mathrm{OBH})\right.} \\
\left.\quad\left(\mathrm{H}_{2} \mathrm{O}\right)_{2} \mathrm{Cl}_{4}\right] \cdot 2 \mathrm{H}_{2} \mathrm{O}\end{array}$ & Nil & $\mathrm{Nil}$ & Nil & Nil & 5.0 \\
\hline$\left[\mathrm{VO}(\mathrm{OBH}-\mathrm{H})_{2}\right] \cdot \mathrm{H}_{2} \mathrm{O}$ & $\mathrm{Nil}$ & $\mathrm{Nil}$ & Nil & $\mathrm{Nil}$ & 5.0 \\
\hline DMSO & $\mathrm{Nil}$ & $\mathrm{Nil}$ & Nil & Nil & Nil \\
\hline Ampicillin & 25 & - & 27 & - & - \\
\hline Gentamicin & - & 48 & 20 & 25.9 & - \\
\hline
\end{tabular}

Reading in diameter $(\mathrm{mm})$

Penicillium and Fusarium and the data are given in Table 9. The data showed that $\left[\mathrm{Zr}(\mathrm{OBH}) \mathrm{Cl}_{4}\right] \cdot 2 \mathrm{H}_{2} \mathrm{O}$ has higher activity against all tested microorganisms except E. coli. The activity is highest and more with Penicillium ( $9 \mathrm{~mm}$ zone inhibition). The higher activity may be due the presence of non-ionizable chlorine and to the less planarity of the complex making it more lipophilic. Most compounds have high activity against Fusarium. $\left[\mathrm{Cu}(\mathrm{OBH})_{2} \mathrm{Cl}_{2}\right] \cdot 2 \mathrm{H}_{2} \mathrm{O}$ has higher value against Fusarium $(15 \mathrm{~mm})$. Comparing these data with that of ampicillin and those obtained for different hydrazone complexes showed more or less activity $[29,30]$.

\section{Conclusion}

Oxalo bis(2,3-butanedionehydrazone) has been prepared and characterized by $\mathrm{x}$-ray crystallography. It coordinates as neutral bidentate; mononegative bidentate and neutral tetradentate. The complexes have tetrahedral, square-planar and/or octahedral structures. The $\mathrm{VO}^{2+}$ and $\mathrm{Co}^{2+}$ complexes have square-pyramid structure. $\left[\mathrm{Cu}(\mathrm{OBH})_{2} \mathrm{Cl}_{2}\right] \cdot 2 \mathrm{H}_{2} \mathrm{O}$ and $\left[\mathrm{Ni}_{2}(\mathrm{OBH}) \mathrm{Cl}_{4}\right] \cdot \mathrm{H}_{2} \mathrm{O} \cdot \mathrm{EtOH}$ decomposed to their oxides while $\left[\mathrm{VO}(\mathrm{OBH}-\mathrm{H})_{2}\right] \cdot \mathrm{H}_{2} \mathrm{O}$ to the metal. The energies from molecular modeling calculation is less in $\left[\mathrm{Ni}_{2}(\mathrm{OBH}) \mathrm{Cl}_{4}\right] \cdot \mathrm{H}_{2} \mathrm{O} \cdot \mathrm{EtOH}$ than those for $\left[\mathrm{Co}(\mathrm{OBH})_{2} \mathrm{Cl}\right] \mathrm{Cl} \cdot 1 / 2 \mathrm{EtOH}$ indicating that the presence of two metals stabilized the complex more than the mono metal. The $\mathrm{Co}(\mathrm{II})$ complex is polar molecule while the $\mathrm{Ni}(\mathrm{II})$ is non-polar.

\section{Further materials}

Crystallographic data for the structure reported in this paper have been deposited with Cambridge
Crystallographic Data Center as supplementary publication CCDC-985982.

\section{Additional file}

Additional file 1: Table S1. Bond lengths and bond angles of the Ni(I) complex. Table S2. Bond lengths and bond angles of the Co(II) complex.

\section{Authors' contributions}

$M A$ and $A E S$ do the experimental part; $A E A$ and $B J$ interpreted the results and wrote the manuscript. All authors read and approved the final manuscript.

\section{Acknowledgements}

This work was supported and funded by Kuwait University Research Grant for the Project SC05/14. The authors acknowledge all service labs in the Faculty of Science, Kuwait University (GS 01/01; GS 01/03; GS 01/05; GS 03/08).

\section{Competing interests}

The authors declare that they have no competing interests.

Received: 4 June 2015 Accepted: 1 October 2015

Published online: 29 December 2015

\section{References}

1. Despaigne AR, Parrilha GL, Izidoro JB, da Costa PR, dos Santos RG, Piro OE, Castellano EE, Rocha WR, Beraldo H (2012) 2-Acetylpyridine- and 2-benzoylpyridine-derived hydrazones and their gallium(III) complexes are highly cytotoxic to glioma cells. Eur J Med Chem 50:163

2. Ranford JD, Vittal JJ, Wang YM (1998) Dicopper(II) complexes of the antitumor analogues acylbis(salicylaldehydehydrazones) and crystal structures of monomeric [Cu(2)(1,3-propanedioyl bis(salicylaldehydehydrazone)) $(\mathrm{H}(2) \mathrm{O})(2)] .(\mathrm{ClO}(4))(2) \cdot 3 \mathrm{H}(2) \mathrm{O}$ and Polymeric-[\{Cu(2)(1,6hexanedioylbis(sal icylaldehydehydrazone $)(\mathrm{C}(2) \mathrm{H}(5) \mathrm{OH})(2)\}(\mathrm{m})()]$. (ClO(4)) (2) (m) ()$\cdot \mathrm{m}(\mathrm{C}(2) \mathrm{H}(5)$ $\mathrm{OH})$. Inorg Chem 37(6):1226

3. El-Asmy AA, Khalifa MI, Hassanian MM (2001) Synthesis and spectroscopic studies on novel transition metal complexes of 3-oximino-3-(2-pyridylcarbamoyl) propane-2-one. Synth React Inorg Met Org Chem 31(10):1787

4. Jayawant AM, Stephenson RE, Ralph JD (1999) 2,3-Butanedione monoxime cardioplegia: advantages over hyperkalemia in blood-perfused isolated hearts. Ann Thorac Surg 67:618

5. Shallaby AM, Mostafa MM, Ibrahim KM, Moussa MNH (1984) New uranyl $(\mathrm{VI})$ complexes with hydrazone-oximes derived from aromatic acid hydrazides and biacetylmonoxime. Spectrochim Acta 40A:999

6. Showalter HDH, Johnson JL, Hoftiezer JM et al (1987) Anthrapyrazole anticancer agents. Synthesis and structure-activity relationship against murine leukemias. J Med Chem 30:121

7. Rostom SAF, Shalaby MA, El-Demellawy MA (2003) Polysubstituted pyrazoles-part 5. Synthesis of new 1-(4-chlorophenyl)-4-hydroxy${ }^{1} \mathrm{H}$-pyrazole-3-carboxylic acid hydrazide analogs and some derived ring systems. A novel class of potential antitumor and anti-HCV agents. Eur J Med Chem 38:959

8. El-Asmy AA, Khalifa MI, Rakha TH, Hassanian MM, Abdallah AM (2000) Mono and trinuclear complexes of oximinoacetoacetyl-pyridine-4-phenylthiosemicarbazone. Chem Pharm Bull 48(1):41

9. Latha KP, Vaidya VP, Keshavayya J (2004) Comparative studies on metal complexes of 2-acetylnaphtho[2,1-b]furan oxime and 2-benzoylnaphtho[2,1-b]furan Oxime. Synth React Inorg Met Org Chem 34:667

10. El-Asmy AA, Khalifa MI, Hassanian MM (2004) Synthesis and characterization of transition metal complexes containing oxime, amido and thioamido groups. Ind J Chem 43A:92

11. Al-Gammal OA, El-Asmy AA (2008) Synthesis and spectral characterization of 1-(amino-N-phenylform)-4-ethylthiosemicarbazide and its metal complexes. J Coord Chem 61(14):2296 
12. Nandy M, Hughes DL, Rosair GM, Singh RKB, Mitra S (2014) Synthesis, characterization, crystal structure and DNA binding of two copper(II)hydrazone complexes. J Coord Chem 67(20):3335

13. West DX, Ives JS, Bain GA, Liberta AE, Martiniz J, Ebert KH (1997) Copper(II) and nickel(II) complexes of 2,3-butanedione bis(N(3)-substituted thiosemicarbazones). Polyhedron 16:1895

14. El-Sayed AEM, Al-Fulaij OA, Elaasar A, El-Defrawy MM, El-Asmy AA (2015) Spectroscopic characterization and biological activity of dihydrazone complexes: crystal structure of 2,3-butanedione bis(isonicotinyl-hydrazone). Spectrochim Acta 135A:211

15. El-Tabl AS, El-Saied FA, Plass W, Al-Hakimi AN (2008) Synthesis, spectroscopic characterization and biological activity of the metal complexes of the Schiff base derived from phenylaminoacetohydrazide and dibenzoylmethane. Spectrochim Acta 71A:90

16. Jeragh B, El-Asmy AA (2014) Spectroscopic and structural study of some 2,5-hexanedione bis(salicyloylhydrazone) complexes: crystal structures of its $\mathrm{Ni}(\mathrm{II})$ and $\mathrm{Cu}(\mathrm{II})$ complexes and N-(2,5-dimethyl-1H-pyrrol-1-yl)2-hydroxybenzamide. Spectrochim Acta 129A:307

17. Al-Fulaij OA, Jeragh BM, El-Sayed AE, El-Defrawy MM, El-Asmy AA (2015) Chelation, spectroscopic characterization and crystal structure of 2,3-butanedione isonicotinylhydrazone: determination of $\mathrm{Zr}^{+4}$ after flotation separation. Spectrochim Acta 136A:1834

18. Geary WJ (1971) The use of conductivity measurements in organic solvents for the characterisation of coordination compounds. Coord Chem Rev 7:81

19. Jeragh B, El-Asmy AA (2014) Coordination of Fe(III), Co(II), Ni(II), $\mathrm{Cu}(\mathrm{II}), \mathrm{Zn}(\mathrm{II}), \mathrm{Cd}(\mathrm{II}), \mathrm{Hg}(\mathrm{II}), \mathrm{Pd}(\mathrm{II})$ and $\mathrm{Pt}(\mathrm{II})$ with 2,5-hexanedione bis(thiosemicarbazone), HBTS: crystal structure of cis-[Pd(HBTS) $] \mathrm{Cl}_{2}$ and 1-(2,5-dimethyl-1H-pyrrol-yl)-thiourea. Spectrochim Acta 130A:546

20. El-Asmy AA, El-Gammal OA, Saleh H (2008) Spectral, thermal, electrochemical and analytical studies on $\mathrm{Cd}(\mathrm{II})$ and $\mathrm{Hg}(\mathrm{II})$ thiosemicarbazone complexes. Spectrochim Acta 71A:39
21. Kumar A, Prasad R, Kociok-Köhn G, Molloy KC, Singh N (2009) Synthesis, crystal structures and properties of sterically congested heteroleptic complexes of group 10 metal ions with p-tolyl sulphonyl dithiocarbimate and 1,2-bis (diphenylphosphino)ethane. Inorg Chem Commun 12:686

22. Patel M, Patel C, Joshi H (2013) Metal-based biologically active compounds: synthesis, characterization, DNA interaction, antibacterial, cytotoxic and SOD mimic activities. Appl Biochem Biotechnol 169:1329

23. West DX, El-Sawaf AK, Bain GA (1998) Metal complexes of N(4) substituted analogs of antiviral drug methisazone (1-methylisatin) thiosemicarbazones. Transit Met Chem 23:1

24. Downes JM, Whelan J, Bosnich B (1981) Inorganic reactions and methods. Inorg Chem 20:1081

25. Ketcham KA, Swearingen JK, Castineiras A, Garcia I, Bermejo E, West DX (2001) Iron(III), cobalt(II, III), copper(II) and zinc(II) complexes of 2-pyridineformamide 3-piperidylthiosemi-carbazone. Polyhedron 20:3265

26. Amer S, El-Wakiel N, El-Ghamry H (2013) Synthesis, spectral, antitumor and antimicrobial studies on $\mathrm{Cu}(\mathrm{II})$ complexes of purine and triazole Schiff base derivatives. J Mol Strut 1049:326

27. Lehmann U, Lach J, Loose C, Hahn T, Kersting B, Kortus J (2013) Binuclear nickel complexes with an edge sharing bis(square-pyramidal) $\mathrm{N}_{3} \mathrm{Ni}\left(\mu-\mathrm{S}_{2}\right)$ $\mathrm{NiN}_{3}$ core: synthesis, characterization, crystal structure and magnetic properties. J Dalton Trans 42:987

28. Perera SD, Fernandez-Sanchez JJ, Shaw BL (2001) Activation of C-X $(\mathrm{X}=\mathrm{Cl}$ or $\mathrm{Br}$ ) bonds in 2-halobenzaldehydes as their 2-pyridylhydrazone derivatives: oxidative addition to tungsten(0) to give aryl-tungsten(II) complexes. Inorg Chim Acta 325:175

29. Amendola V, Boiocchi M, Brega V, Fabbrizzi L, Mosca L (2010) Octahedral copper(II) and tetrahedral copper(II) double-strand helicates: chiral selfrecognition and redox behavior. Inorg Chem 49:997

30. El-Dissouky A, Al-Fulaij O, Awad MK, Rizk S (2010) Synthesis, characterization, and biological activity studies of copper(II)-metal(II) binuclear complexes of dipyridylglyoxal bis(2-hydroxybenzoyl hydrazone). J Coord Chem 63:330 